\title{
Comparative Water Relations of Two Contrasting Date Palm Genotypes under Salinity
}

\author{
Latifa Al Kharusi, ${ }^{1}$ Ramanjulu Sunkar, ${ }^{2}$ Rashid Al-Yahyai, ${ }^{3}$ and Mahmoud W. Yaish (D) \\ ${ }^{1}$ Department of Biology, College of Science, Sultan Qaboos University, P.O. Box 36, 123 Muscat, Oman \\ ${ }^{2}$ Department of Biochemistry and Molecular Biology, Oklahoma State University, Stillwater, Oklahoma, USA \\ ${ }^{3}$ Department of Crop Sciences, College of Agricultural and Marine Sciences, Sultan Qaboos University, P.O. Box 34, \\ 123 Muscat, Oman
}

Correspondence should be addressed to Mahmoud W. Yaish; myaish@squ.edu.om

Received 24 May 2019; Revised 13 September 2019; Accepted 9 October 2019; Published 11 November 2019

Academic Editor: Allen Barker

Copyright (c) 2019 Latifa Al Kharusi et al. This is an open access article distributed under the Creative Commons Attribution License, which permits unrestricted use, distribution, and reproduction in any medium, provided the original work is properly cited.

\begin{abstract}
Salinity is a global agricultural problem, resulting in a significant reduction in the plantation areas and the crop yields, especially in arid and semiarid regions. The date palm is relatively salt-tolerant plant species, although the nature of salt tolerance is poorly understood. In this study, the salt stress responses of a salt-tolerant "Umsila" was compared with salt-susceptible "Zabad" date palm cultivars. Various physiological parameters, plant-water relations, and anatomical characteristics were analyzed. The results revealed that although salinity has negatively affected both cultivars, Umsila exhibited more stable photosynthesis than Zabad as reflected by the quantum yield (Qy) and the stomatal conductance (GS). Similarly, Umsila showed a more dynamic root system and efficient water relations than Zabad as demonstrated by the leaf water potential (LWP) and relative water content (RWC) during salinity. Umsila also accumulated greater abundances of soluble sugars, potassium $\left(\mathrm{K}^{+}\right)$, calcium $\left(\mathrm{Ca}^{+2}\right)$, proline, glycine betaine, and lignin and formed extra layers of Casparian strips in the root tissues when the seedlings were grown under saline conditions. Together, the results obtained from this study have offered some insights into the salt tolerance mechanisms in the date palm.
\end{abstract}

\section{Introduction}

Salinity is a worldwide problem resulting in a major reduction in growth and productivity of the crop plants [1]. Important fruit trees such as the date palm (Phoenix dactylifera L.) are growing in increasingly saline environments in the Arabian Peninsula, resulting in a significant reduction in the annual yield. For an instant, in Oman, $70 \%$ of the cropping areas have been affected by salinity [2]. Salt-tolerant plants use different mechanisms as revealed by several studies [3]. These mechanisms include the reduced $\mathrm{Na}^{+}$ uptake, accumulation of $\mathrm{Na}^{+}$in the vacuoles, the retrieval of $\mathrm{Na}^{+}$from the xylem vessels into the xylem parenchyma cells, and the recirculation of $\mathrm{Na}^{+}$from the shoot to root and eventually back to the soil through the phloem $[1,4-6]$.

Determination of salt tolerance mechanism in the date palm requires global omics analysis and rigorous physiological studies [2]. Despite the fact that the association between transcriptomics [7-9], metabolomics [10], and biochemical analyses [11-13] with salinity tolerance was investigated in the date palm, the importance of physiological parameters including water relations has not been thoroughly studied.

Besides the sodium and chloride toxicity, salt stress is known to interfere with the plant-water relations [14-16], affecting osmotic potential and altering cell water turgidity $[17,18]$, provoking stomatal closure, reducing leaf expansion [19], and impairing photosynthesis [20, 21]. Under salinity, plants adjust their osmotic potential to maintain cell turgor pressure $[15,18,22]$. This procedure involves chiefly osmolytes such as soluble sugars and proline, and other compatible solutes but also certain modifications in the water movement system, which requires lignin and suberin structures [23].

Salinity is enhanced by antioxidant production, which is affected by various factors such as plant hormones and nitric oxide $[24,25]$. Water movement through the apoplast and the stomatal aperture, as well as the symplastic movement 
via aquaporins across the membranes, is mediated by $\mathrm{Ca}^{2+}[26]$. $\mathrm{Ca}^{2+}$ acts as an osmoticum within vacuoles and protects the plasma membrane against $\mathrm{Na}^{+}$toxicity by accumulating in the cytoplasm, as well as serves as an essential secondary messenger in the processes associated with cell division, expansion, and photosynthesis [27]. Salinity is known to decrease $\mathrm{Ca}^{2+}$ accumulation in plants [28]. Consistently, the exogenous application of $\mathrm{Ca}^{2+}$ reduces the negative effects of salt stress by increasing the $\mathrm{K}^{+} / \mathrm{Na}^{+}$ratios and improving the antioxidant defense and glyoxalase systems in rice subjected to salt stress [28].

The accumulation of sugars in plants promotes tolerance to salinity by balancing the osmotic potential inside the cell with the external salt concentration, thereby reducing further water loss [29]. Sugars, including starch, occupy a significant percentage of the plant dry weight, and it is also a major source of cellular energy that is required for routine growth and development. Interestingly, the degradation of starch to less complicated sugars under osmotic stress enhances cellular osmoprotection and elevated scavenging activities against reactive oxygen species (ROS) [30].

Lignin is a complex aromatic phenylpropanoid polymer and is a significant component of the secondary cell wall $[31,32]$. In general, endodermis tissue is composed of the Casparian strip which consists of a ring of lignin deposited around the endodermal cells and acts as a barrier for water and solute repellants $[33,34]$. Salinity induces changes in the cell wall components of root tissues, including an increased deposition of lignin and suberin, which in turn may prevent water loss and alter ion transport pathways [32]. Further, lignification is considered as a defense mechanism in plants [35] because lignin acts as a mechanical support and contributes to the rigidity of cell wall in plants and solute transport across the plants [36].

The purpose of this study was to identify the differences between salt-tolerant "Umsila" and salt-sensitive "Zabad" date palm cultivars concerning water relations, photosynthesis, sugars, proline, glycine betaine, lignin, $\mathrm{Na}^{+}, \mathrm{K}^{+}$, and $\mathrm{Ca}^{2+} \mathrm{ac}^{-}$ cumulation during salinity. The results revealed that ion and osmolyte accumulations, photosynthesis, and water system might play an essential role in salinity tolerance in the date palm.

\section{Materials and Methods}

2.1. Plant Growth Condition and Salt Treatment. Seeds of date palm (Phoenix dactylifera L.) fruits, cultivars Umsila and Zabad, were thoroughly washed and then soaked in water overnight. The seeds were sterilized with $75 \%$ ethanol for one minute and then rinsed three times with sterile water. Subsequently, the seeds were mixed into a sterilized wet vermiculite bag and incubated at $37^{\circ} \mathrm{C}$ until germination, which were then transplanted into $2 \mathrm{~L}$ pots filled with the sand soil medium. For the establishment, germinated seeds were irrigated using distilled water and covered with clear plastic for two weeks until the first visible sign of shooting was observed. Afterward, seedlings were either irrigated with distilled water (control) or with $240 \mathrm{mM} \mathrm{NaCl}$ solution (salt stress) for six weeks. This level of $\mathrm{NaCl}$ salinity was known to induce unlethal salt stress for the seedlings [12]. The growing seedlings were fertilized with the all-purpose NPK (14-10-
27) fertilizer $(0.05 \mathrm{~g} / \mathrm{L})$ (Phostrogen, Bayer Garden, UK), twice a month. The fertilizer included all essential macroand microtrace elements. Pots were incubated in the glasshouse under natural sunlight and at a constant temperature of $30^{\circ} \mathrm{C}$. The electrical conductivity (EC), moisture content, and temperature of the soil were monitored by using data loggers (DECAGON, Em50, 2012, WV, USA). Each treatment had three biological replicates, and each replicate included three different plants. At the end of the stress treatment, leaf and root tissues of the control and treated seedlings were separated, thoroughly rinsed with water or a $240 \mathrm{mM}$ salt solution, dried using paper towels, and immediately frozen in liquid nitrogen.

\subsection{Photosynthesis and Chlorophyll Fluorescence} Measurements. Gas exchange parameters such as the net photosynthetic rate $(A)$, stomatal conductance (gs), transpiration rate $(E)$, and intercellular $\mathrm{CO}_{2}$ concentration $\left(C_{i}\right)$ were determined using a portable photosynthesis system (LCpro-SD, ADC BioScientific, UK). Photosynthetic flux density was maintained at $869 \mu \mathrm{mol} \cdot \mathrm{m}^{-2} \cdot \mathrm{s}^{-1}$, and reference $\mathrm{CO}_{2}$ was maintained at a rate of $600 \mu \mathrm{mol} \mathrm{CO}_{2} / \mathrm{mol}$. Transpiration use efficiency (TUE) was calculated as the following: $\mathrm{WUE}=\mathrm{A} / \mathrm{E}$. Chlorophyll fluorescence $(\mathrm{Fv} / \mathrm{Fm})$ was measured using a rapid screening fluorometer (Pocket Pea, Hansatech Instruments, UK). The values recorded from the fluorometer were analyzed using PEA software.

2.3. Leaf Water Relations. The relative water content was measured as previously described $[37,38]$. Leaf water potential (LWP) was determined using a leaf water potential meter (model 600, PMS Instrument Company, Oregon, USA). Osmotic potential (OP) was measured on the sap extracted from leaves and roots of the two cultivars using a vapor pressure osmometer(VAPRO@ Pressure Osmometer, Modele 5600, TX, USA), and the OP at full turgor (OPft) was calculated as previously described [39]. Osmotic adjustment (OA) was then calculated as the difference between OP at full turgor of control and treated plants. The leaf area (LA) of each plant was determined using a portable leaf area meter (CI-202, USA).

2.4. Root Measurements. Root measurements (length, diameter, total surface area, volume, and number of tips) were carried out using root scanner WinRHIZO (RH-R XLR STD) software (version 5.0, Reagent instruments, Inc., Quebec, Canada).

2.5. Total Soluble Sugar Measurements. The total soluble sugars in samples were calorimetrically determined using a previously reported protocol [40]. In brief, $0.5 \mathrm{~g}$ of tissue was powdered in $80 \%$ ethanol, vortexed vigorously, and boiled at $80^{\circ} \mathrm{C}$ for 30 minutes. The mixture was then centrifuged at $10,000 \mathrm{~g}$ for 15 minutes, and the supernatant was collected. Subsequently, $2 \mathrm{~mL}$ of the extract was added to $2 \mathrm{~mL}$ of the anthrone reagent on ice, and the mixture was boiled for seven and a half minutes in boiling water bath before the solution could be cooled rapidly. The absorbance readings 
were measured at $620 \mathrm{~nm}$. A standard curve was prepared using glucose stock solution ( $100 \mathrm{mg}$ glucose $/ 100 \mathrm{~mL} \mathrm{dH}_{2} \mathrm{O}$ ), and total sugars were expressed as $\mathrm{mg} / \mathrm{g}$.

2.6. Determination of $\mathrm{Ca}^{2+}, \mathrm{K}^{+}$, and $\mathrm{Na}^{+}$in Plant Tissues. The concentration of $\mathrm{Ca}^{2+}$ was determined in plant tissues using the established protocol [41]. In brief, leaf and root samples were dried at $80^{\circ} \mathrm{C}$ for $48 \mathrm{~h}$ and weighed. The dried samples were digested with $69 \% \mathrm{HNO}_{3}$ acid and $\mathrm{H}_{2} \mathrm{O}_{2}(5: 1 \mathrm{v} /$ $v)$, and $\mathrm{Ca}^{2+}$ concentration was measured by using an atomic absorption spectrophotometer Analyst H 300 (Germany). Subsequently, the $\mathrm{Na}^{+}$and $\mathrm{K}^{+}$concentrations were quantified using the flame photometer (microprocessor flame photometer, Electronics India, Model 1382, Parwanoo, Himachal Pradesh, India) against $\mathrm{Na}^{+}$and $\mathrm{K}^{+}$standards of known concentration, following a previously described method [42].

\subsection{Determination of Lignin and the Compatible Solutes.} Quantification of lignin was carried out using the thioglycolic acid method as previously described [43]. Root tissues $(0.2 \mathrm{~g})$ was powdered in liquid nitrogen and incubated in $85 \%$ acetone for $48 \mathrm{~h}$. The mixture was then centrifuged at $7,500 \times g$ for $15 \mathrm{~min}$ at $7^{\circ} \mathrm{C}$, and the supernatant was discarded. The pellet was air-dried and resuspended in $5 \mathrm{~mL}$ thioglycolic acid prepared in $2 \mathrm{~N} \mathrm{HCL}(1: 10 \mathrm{v} / \mathrm{v})$ and incubated for $4 \mathrm{~h}$ at $25^{\circ} \mathrm{C}$. Subsequently, the suspension was centrifuged at $7,500 \times g$ for $15 \mathrm{~min}$, and the resulted supernatant was transferred into a $20 \mathrm{~mL}$ tube containing $0.2 \mathrm{~mL}$ of $10 \mathrm{M} \mathrm{HCl}$ and incubated in an ice bath for $4 \mathrm{~h}$. The supernatant was centrifuged at $7,500 \times g$ for $30 \mathrm{~min}$ at $7^{\circ} \mathrm{C}$, and the pellet was resuspended in $5 \mathrm{~mL}$ of $0.5 \mathrm{~N} \mathrm{NaOH}$. Absorbance was determined at $280 \mathrm{~nm}$. The standard curve was prepared using lignin alkali (10$100 \mu \mathrm{g} / \mathrm{mL}$ ), and the data were expressed as $\mu \mathrm{g} / \mathrm{g}$ DW. Proline and glycine betaine (GB) concentrations were determined by a colorimetric method, according to previously published protocols $[44,45]$.

2.8. Root Sections and Staining Procedure. To determine the changes in the Casparian band formation, seeds of Umsila and Zabad cultivars were germinated in wet sand and the seeds were irrigated either with distilled water or with a $240 \mathrm{mM} \mathrm{NaCl}$ solution and incubated in a growth chamber in the dark at $30^{\circ} \mathrm{C}$ for six weeks. Freehand cross-sections were taken from the root vascular tissues $1 \mathrm{~cm}$ away from the root tip and stained for $1 \mathrm{~h}$ in $0.1 \%(\mathrm{w} / \mathrm{v})$ berberine chloridehydrate and transferred to $0.5 \%(\mathrm{w} / \mathrm{v})$ aniline-blue for 30 minutes as previously described [46]. Then, stained sections were examined and viewed under an epifluorescent microscope (NIKON MODEL ECLIPS, DS-Ri2, TOKYO, JAPAN), with UV light using an excitation filter for $4^{\prime}, 6-$ diamidino-2-phenylindole (DAPI) (EF: 361-389) and a dichroic mirror (DM- 415, NIKON).

2.9. Statistical Analysis. Data were analyzed by using the SPSS statistical package version 21 (IBM Corp, Armonk NY, USA). The test of significance was carried out using pairwise comparison, F-statistics at $p \leq 0.05$.

\section{Results}

3.1. The Effect of Salinity on the Leaf and Root Tissues. In general, salt stress negatively affected the growth and development of both cultivars. However, both leaf and root systems of Umsila cultivar exhibited better performance than the Zabad (Figure 1(a)). For instance, Umsila exhibited approximately $20 \%$ reduction in the leaf area compared with the control, whereas the leaf area in Zabad was more significantly reduced by $27 \%$ under salt stress (Figure $1(\mathrm{~b})$ ).

Without salt stress (control), the total surface area of the roots was significantly $(p \leq 0.05)$ higher in Umsila than in Zabad. Some of the root architecture measurements were negatively affected by salt stress in both cultivars. However, unlike in Zabad, the total root length, surface area, and volume were decreased to a lesser extent $(p \leq 0.05)$ in Umsila. By contrast, total diameter and number of tips were significantly $(p \leq 0.05)$ increased in response to salinity in Umsila but not in Zabad (Figure 2).

3.2. The Effect of Salinity on Photosynthesis. The net photosynthetic rate $(A)$, stomatal conductance $(g s)$, transpiration $(E)$ and internal $\mathrm{CO}_{2}$ concentration $\left(C_{i}\right)$, transpiration use efficiency (TUE), and quantum yield of PSII activity (Qy) were determined in leaves of Umsila and Zabad grown under control and salinity. Most of these parameters were significantly $(p \leq 0.05)$ reduced in both cultivars when exposed to salinity, although the extent of decrease was greater in salt-sensitive Zabad than salt-tolerant Umsila. The only exception to this general decreasing trend was, TUE which was significantly increased under salinity in Zabad while it was decreased in Umsila (Figure 3(e)). For instance, the percent reduction in $A$ was lower in Umsila (34\%) $(p \leq 0.05)$ than in Zabad $(48 \%)$ when compared with their respective controls (Figure 3(a)). Similarly, the reduction in gs was less in Umsila (38\%) than in Zabad $(67 \%)(p \leq 0.05)$ compared with their respective control plants (Figure 3(b)). The decrease in $C_{i}$ was also less in Umsila $(30 \%)$ than in the control, whereas it was significantly reduced $(p \leq 0.05)$ in Zabad (50\%) (Figure 3(c)). Additionally, the reduction in $E$ was less in Umsila (21\%) compared with the control, whereas it was significantly reduced $(p \leq 0.05)$ in Zabad (62\%) (Figure 3(d)). A similar pattern was observed for the transpiration use efficiency (TUE) where it was reduced in Umsila by $17 \%$ when compared with the control (Figure 3(e)). For the quantum yield of PSII activity, the degree of reduction was less (14\%) in Umsila, whereas this parameter was markedly reduced (26\%) in Zabad (Figure 3(f)).

3.3. The Effect of Salinity on Plant-Water Relations. Salinity induces osmotic stress both in the soil and in the plant, which disturbs plant-water relations (turgor). However, the degree of disturbance in the plant cell may vary based on the plant's ability to deal with salinity. The leaf water potential (LWP) was significantly $(p \leq 0.05)$ decreased both in Umsila and Zabad during salinity (Figure 4(a)). However, the extent of reduction in water potential is much greater in Zabad than in Umsila. The relative water content (RWC) of leaves of Umsila remained unchanged, whereas it 


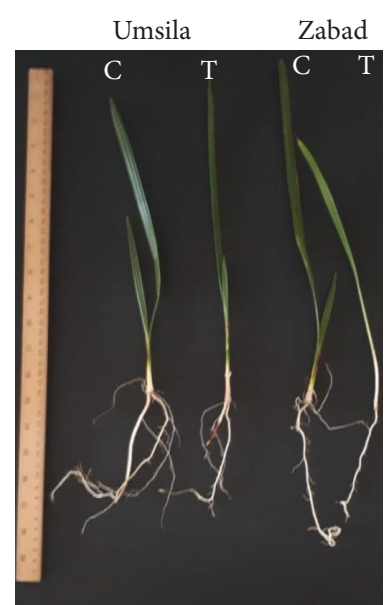

(a)

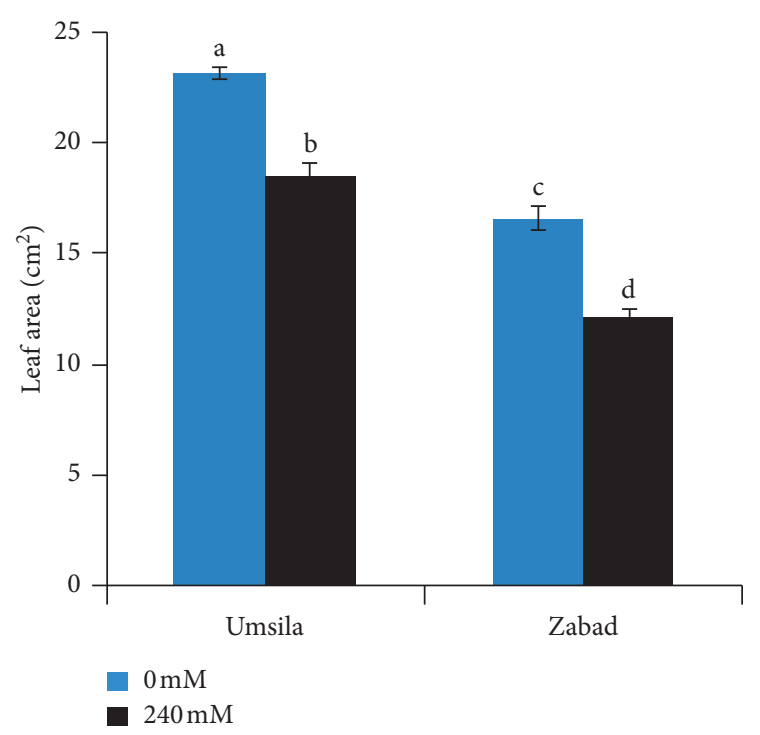

(b)

FIGURE 1: Seedlings phenotype (a) and leaf area (b) of Umsila and Zabad date palm cultivars grown under control and salt stress (240 mM $\mathrm{NaCl})$ conditions. Bars represent mean $\pm \mathrm{SE}(n=3)$. Statistical differences between the treatments were calculated based on $(p \leq 0.05)$.

was significantly $(p \leq 0.05)$ reduced in Zabad in response to salinity (Figure 4(b)). Similarly, during salt stress, the leaf osmotic potential (leaf OP) of Umsila was only mildly decreased, whereas it was significantly $(p \leq 0.05)$ decreased in Zabad when compared with their respective controls (Figure 4(c)).

Interestingly, the root osmotic potential (root OP) greatly varied between Umsila and Zabad under control conditions, i.e., root OP was much greater in Umsila than in Zabad. During salt stress, OP was reduced in both cultivars but the degree of decrease was significant $(p \leq 0.05)$ in Zabad (Figure $4(\mathrm{~d})$ ). Without stress treatment or during salt stress, the osmotic potential at full turgor (OPft) of the leaf tissues was almost similar between Umsila and Zabad (Figure 4(e)). However, the osmotic adjustment (OA) was significantly $(p \leq 0.05)$ greater in the leaf and root tissues of Umsila but remained low in Zabad tissues when grown under control and salinity conditions (Figure 4(f)).

3.4. The Effect of Salt Stress on $\mathrm{Na}^{+}, \mathrm{K}^{+}$, and $\mathrm{Ca}^{2+}$ Concentrations. The concentration of $\mathrm{Na}^{+}$and $\mathrm{K}^{+}$was measured in order to determine the effect of salinity on the accumulation of these ions in the plant tissues. The results showed that the concentration of $\mathrm{Na}^{+}$was significantly $(p \leq 0.05)$ increased in the plant tissues with respect to the control when both cultivars were exposed to salinity. However, that increase was remarkably higher in Zabad tissues (Figures 5(a) and 5(b)). Unlike Umsila, the concentration of $\mathrm{K}^{+}$was significantly $(p \leq 0.05)$ reduced in the leaf and root tissues of Zabad when exposed to salinity (Figures 5(c) and 5(d)). The reduction in $\mathrm{K}^{+}$and the increase in $\mathrm{Na}^{+}$led to an increase in the $\mathrm{Na}^{+} / \mathrm{K}^{+}$ratio only in the leaf and root tissues of Zabad cultivar (Figures 5(e) and 5(f)).
This increase has a negative impact on the ability of the plants to tolerate salinity.

The concentration of $\mathrm{Ca}^{2+}$ in the plant tissues was measured in leaf and root tissues in order to determine the effect of salinity on $\mathrm{Ca}^{2+}$ accumulation in both date palm cultivars. The $\mathrm{Ca}^{2+}$ concentration was significantly $(p \leq 0.05)$ increased in 'Umsila' leaf tissues in response to salinity (Figure 6(a)). Surprisingly, $\mathrm{Ca}^{+2}$ concentration in the root tissues was almost unaltered under salt stress in both cultivars (Figure 6(b)).

\subsection{Differentially Accumulated Sugars in Response to Salinity.} Total soluble sugars were measured in the leaf and root tissues of Umsila and Zabad plants grown under control and saline conditions. In general, leaf tissues had more soluble sugars than root tissues of both cultivars. The level of soluble sugars in the leaf and the root tissues of both cultivars was almost similar under control conditions (Figure 7). However, under salt stress, the total sugars were significantly $(p \leq 0.05)$ elevated in the leaf and root tissues of Umsila but not in Zabad.

\subsection{The Accumulation of Proline and Glycine Betaine in Re-} sponse to Salinity. Proline and glycine betaine are important compatible solutes that may provide plants with osmoprotection under salinity. Therefore, the concentration of these osmolytes was measured in this experiment in order to determine their role in salinity tolerance in the date palm. The results showed that the concentration of proline was higher than glycine betaine in date palm tissues, and the concentration of proline was higher in the leaves than in the roots (Figures $8(\mathrm{a})$ and $8(\mathrm{~b})$ ). When the seedlings were exposed to salinity, the concentration of proline was significantly $(p \leq 0.05)$ increased in the leaf and root tissues of Umsila; however, this concentration was significantly 


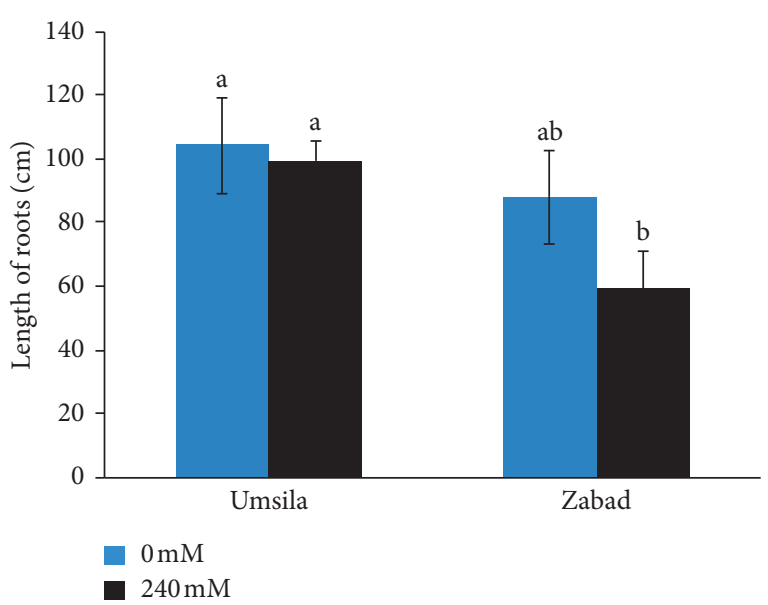

(a)

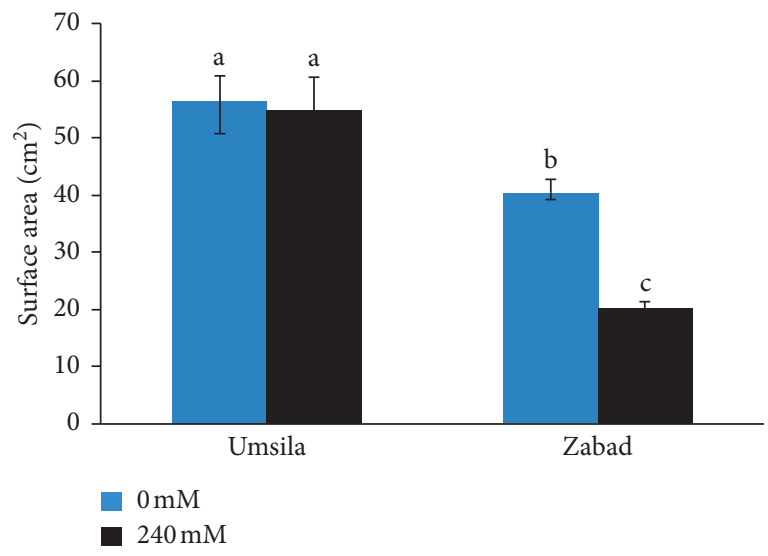

(c)

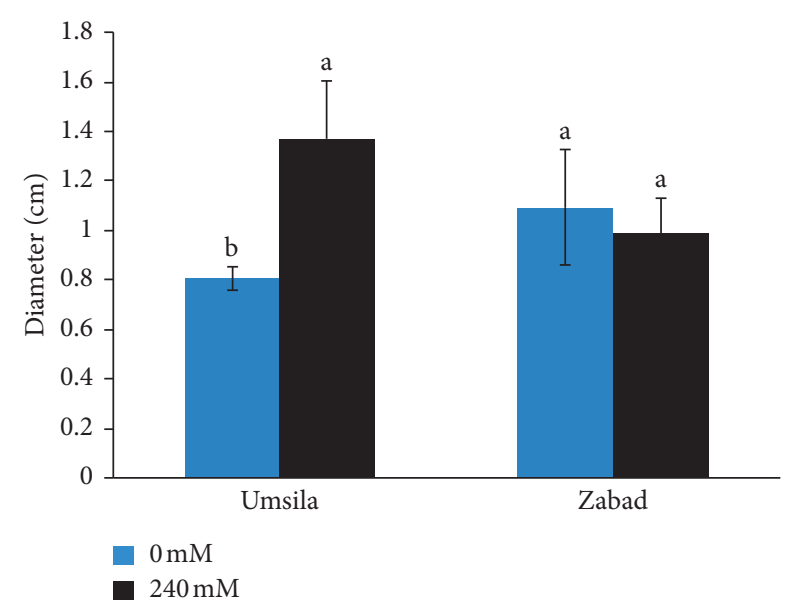

(b)

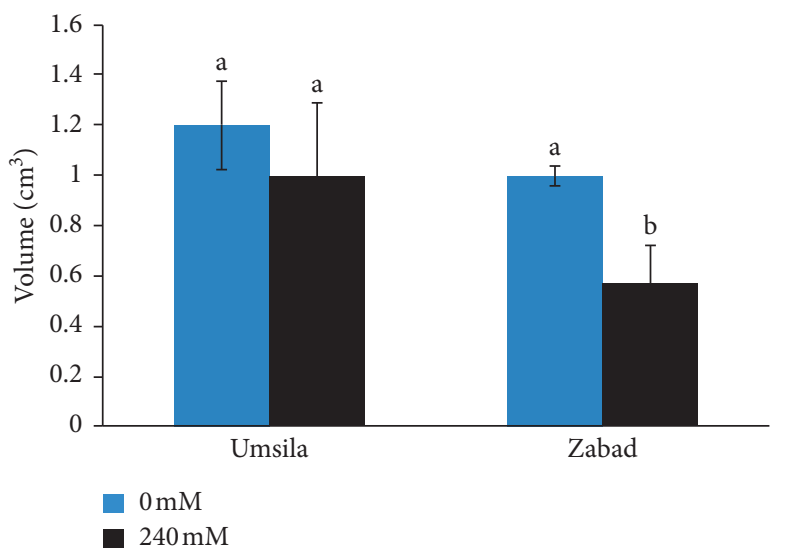

(d)

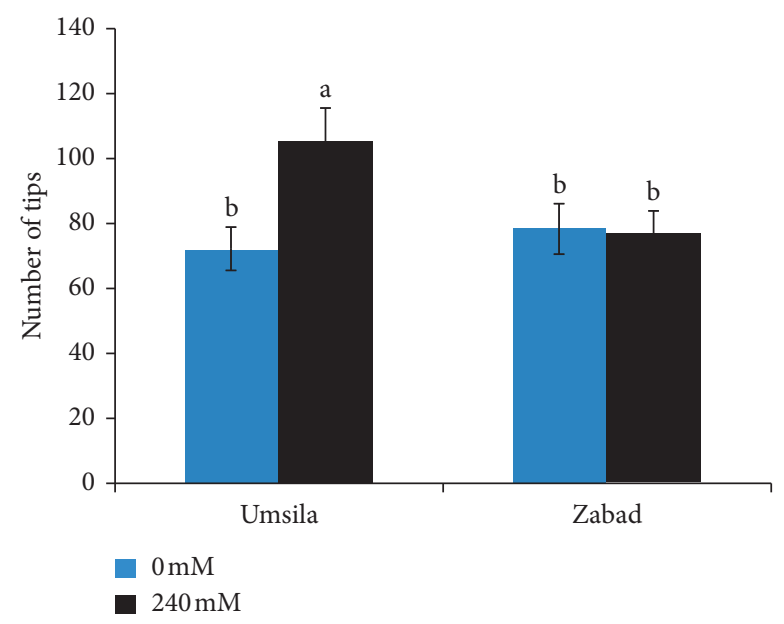

(e)

Figure 2: Measurements obtained for the root system including the length (a), diameter (b), total surface area (c), volume (d), and number of tips (e) of Umsila and Zabad seedlings grown under control and saline conditions. Bars represent mean \pm SE $(n=3)$. Statistical differences between the treatments were calculated based on $(p \leq 0.05)$.

reduced in Zabad tissues (Figures 8(a) and 8(b)). Likewise, the concentration of glycine betaine was significantly $(p \leq 0.05)$ increased in the leaf tissues of Umsila, but it was reduced in Zabad in response to salinity (Figures $8(\mathrm{c})$ and $8(\mathrm{~d})$ ).
3.7. The Effect of Salt Stress on Lignin Levels. Total lignin content was quantified in the root tissues of Umsila and Zabad under control and salinity. The lignin levels in the untreated plants of Umsila was slightly higher than Zabad. 


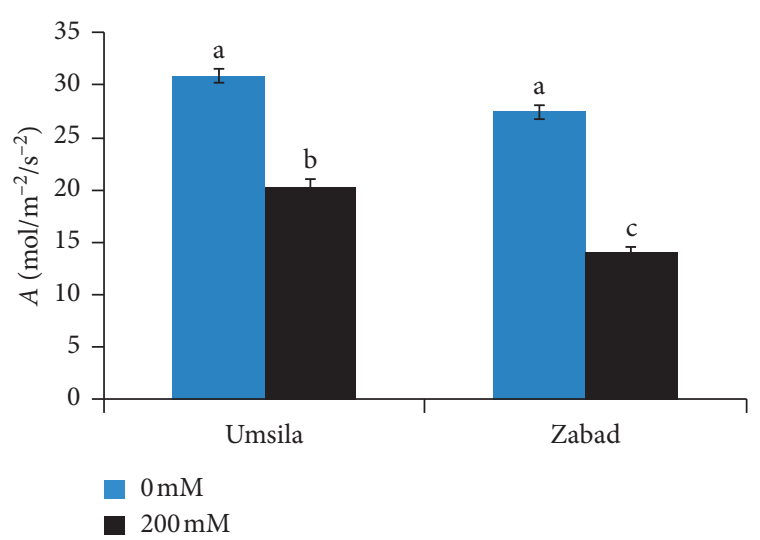

(a)

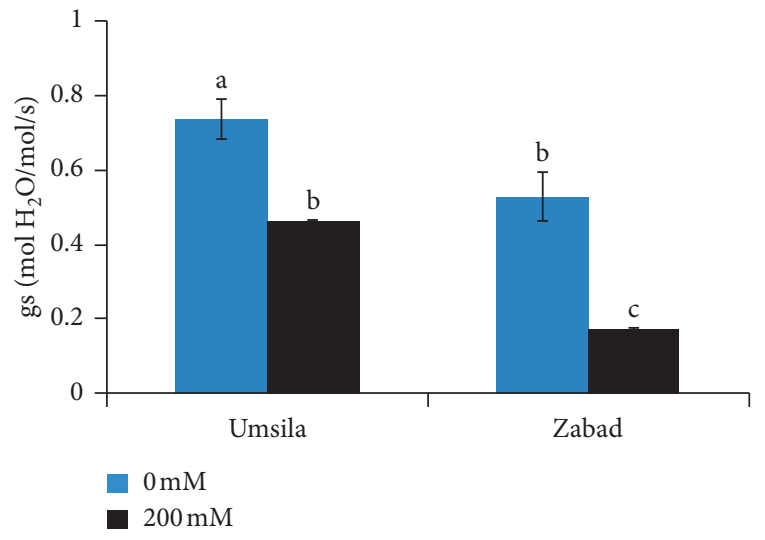

(c)

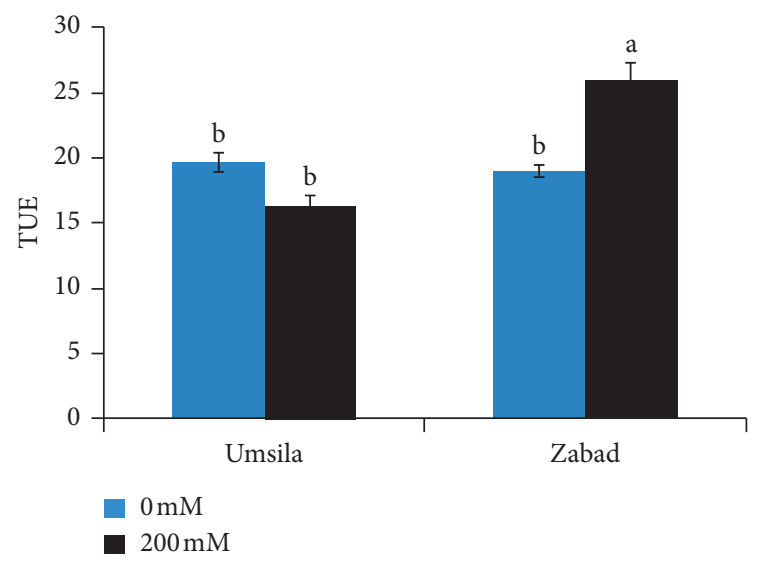

(e)

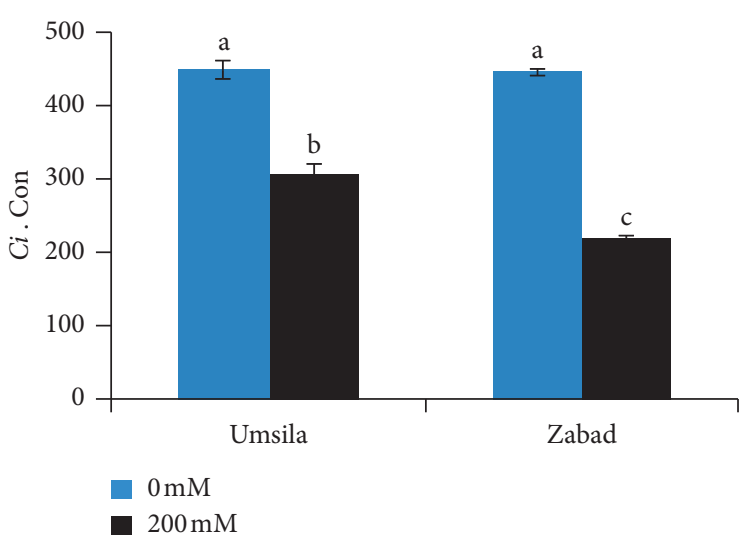

(b)

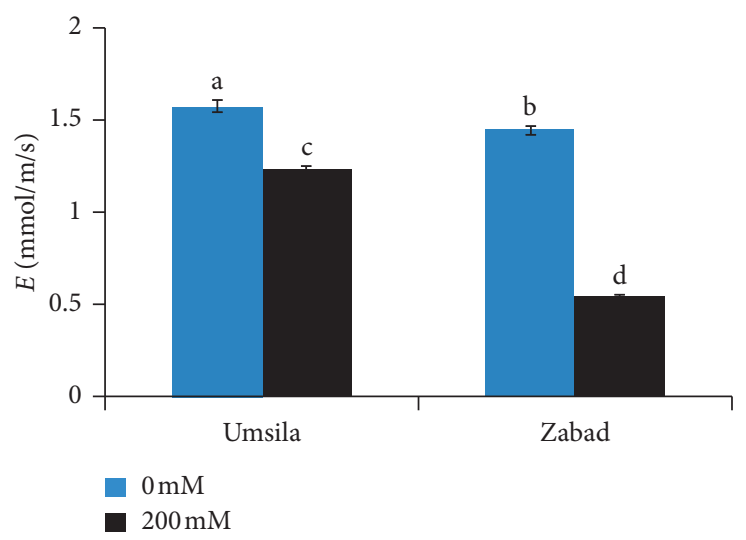

(d)

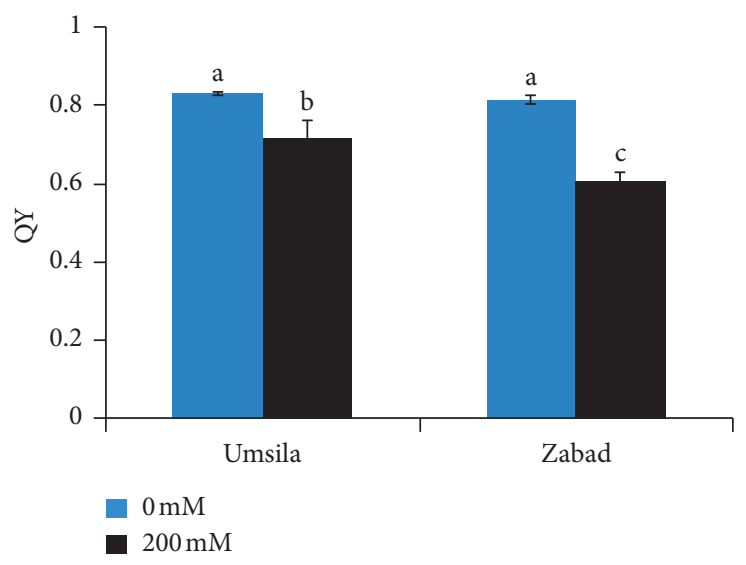

(f)

FIgURE 3: Effect of salinity on photosynthesis rate $(A)$ (a), intercellular $\mathrm{CO}_{2}$ concentration (Ci) (b), stomatal conductance (gs) (c), transpiration use efficiency (TUE) (d), water use efficiency (WUE) (e), and quantum yield (Qy) (f) in Umsila and Zabad date palm cultivars exposed to control and salinity. Bars represent means \pm SE $(n=3)$. Bars with the same letter are not significantly different at the $p \leq 0.05$ level.

However, the lignin in the root of Umsila was slightly higher than those in Zabad under salinity (Figure 9).

\subsection{Salinity Promotes Casparian Strip Formation in Umsila.} Casparian strips tissue can regulate selective water and mineral transportation and hence contribute to salinity tolerance in plants. A histochemical staining technique was used to investigate the role of Casparian strips in salinity tolerance of date palm cultivars Umsila and Zabad. Staining and measuring of the Casparian strip under the fluorescent microscope revealed a significant $(p \leq 0.05)$ increase in the thickness of the Casparian strips of Umsila plants exposed to salinity (Figure 10(a)), whereas there was a significant $(p \leq 0.05)$ decrease in this tissue of Zabad cultivar (Figure 10(b)). 

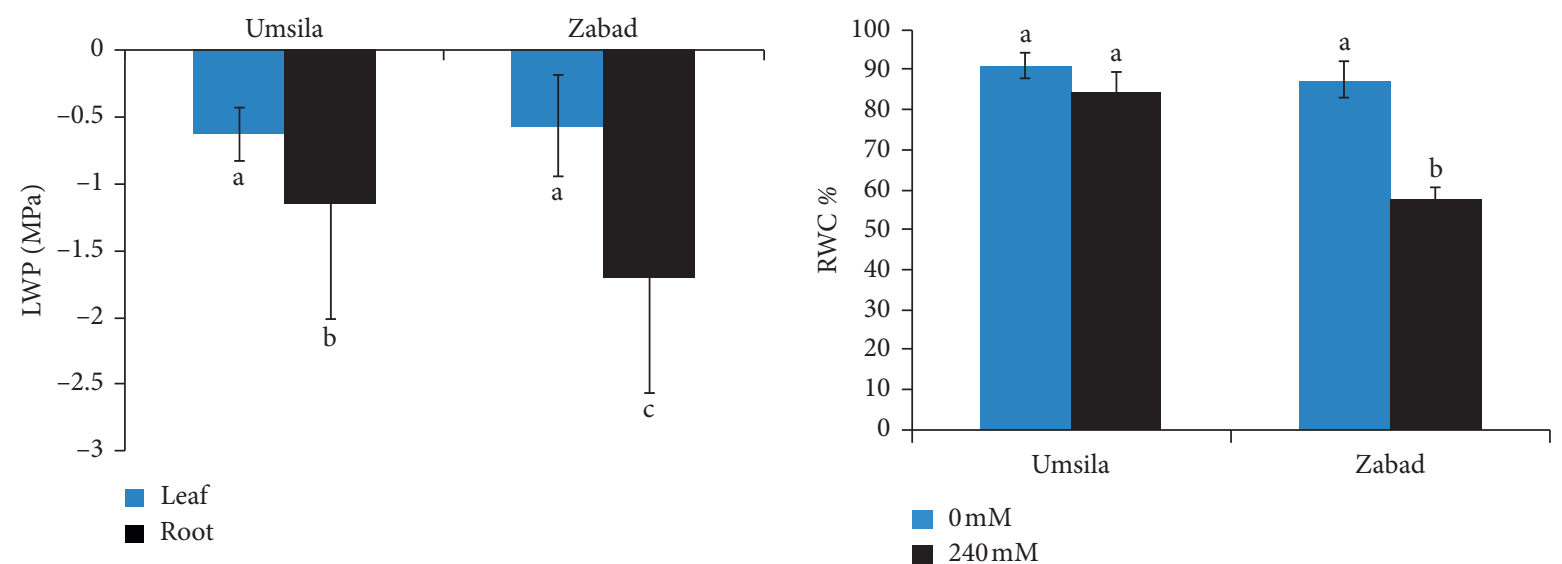

(a)
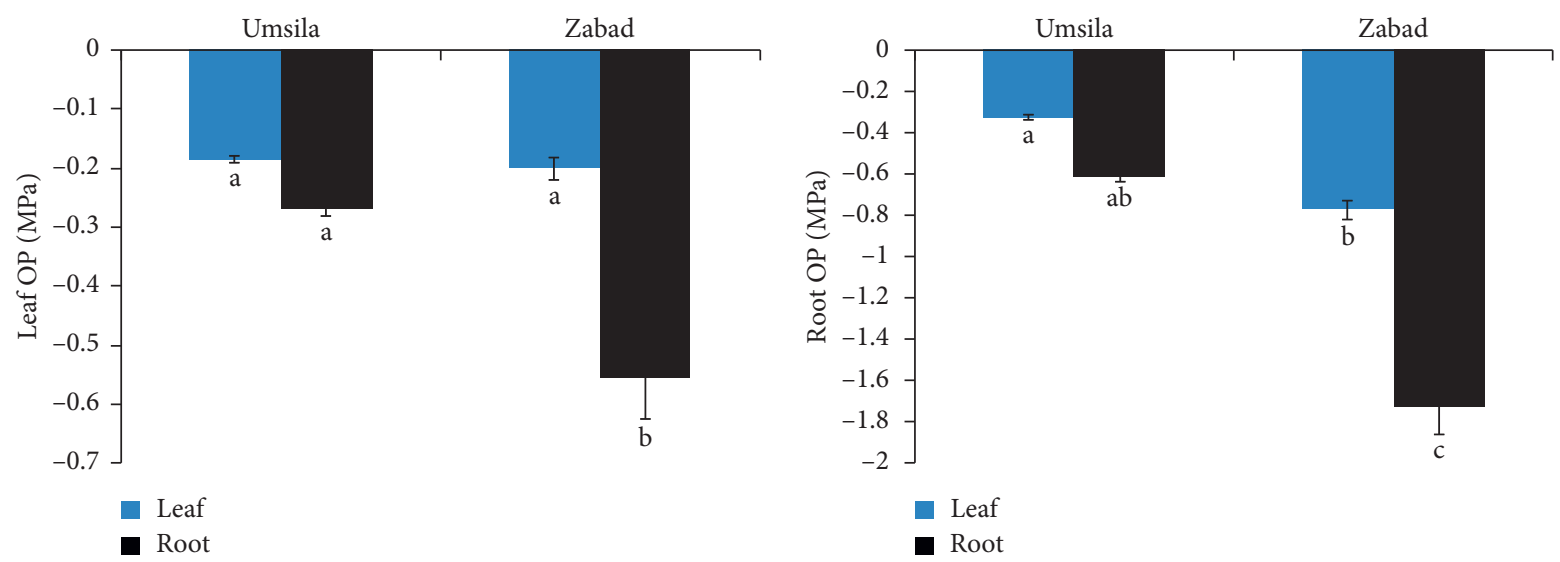

(c)
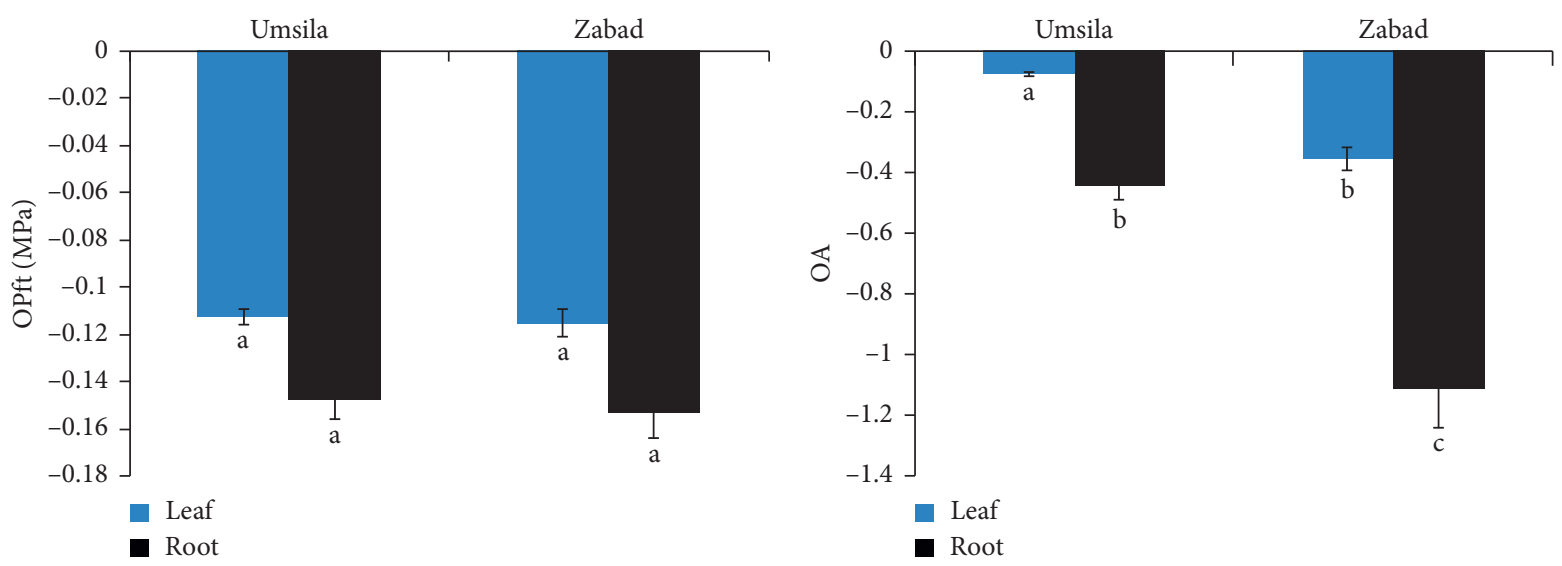

(e)

(f)

FIGURE 4: Leaf water potential (LWP) (a), relative water content (RWC) (b), leaf osmotic potential (leaf OP) (c), root osmotic potential (root $\mathrm{OP})(\mathrm{d})$, osmotic potential at full turgor (OPft) (e), and osmotic adjustment (OA) (f) measured in Umsila and Zabad date palm cultivars when grown under control and salinity conditions. Bars represent mean $\pm \mathrm{SE}(n=3)$. Statistical differences between the treatments were calculated based on $p \leq 0.05$.

\section{Discussion}

Salinity tolerance is a complex trait involving several pathways and mechanisms that in turn, offer protection to the plant against the harmful effects of salinity. In this study, two date palm cultivars differing in their salinity tolerance capacities were evaluated for water relations, photosynthesis-associated parameters, sugars as well as lignin, and casparian strips to identify the differences between salttolerant and salt-sensitive date palm cultivars.

Overall, the adverse effects of salt stress were less severe on the growth parameters of Umsila, a tolerant date palm 


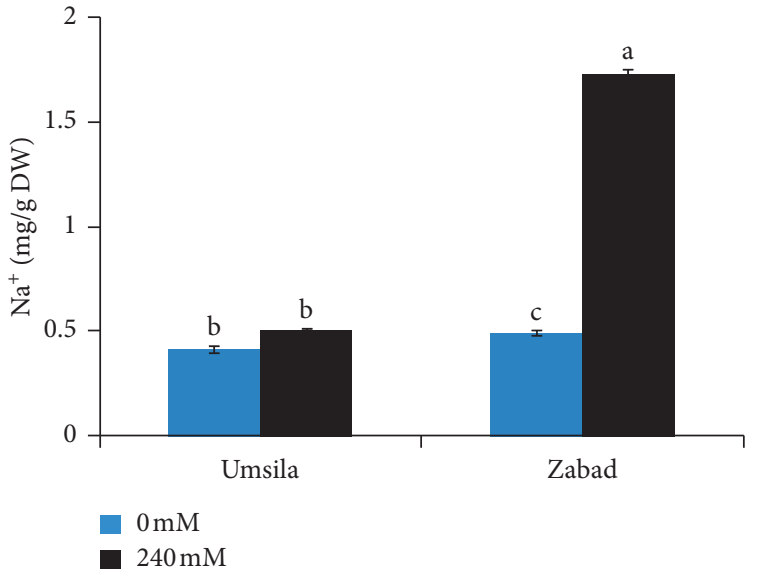

(a)

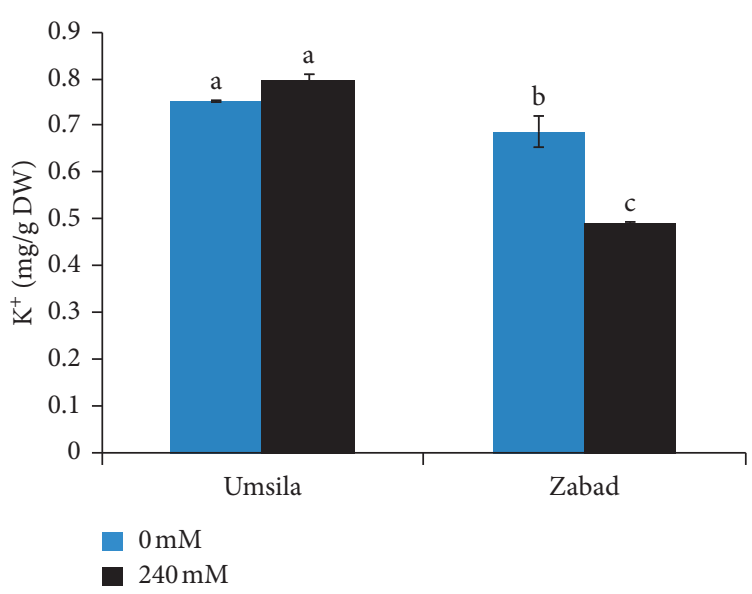

(c)

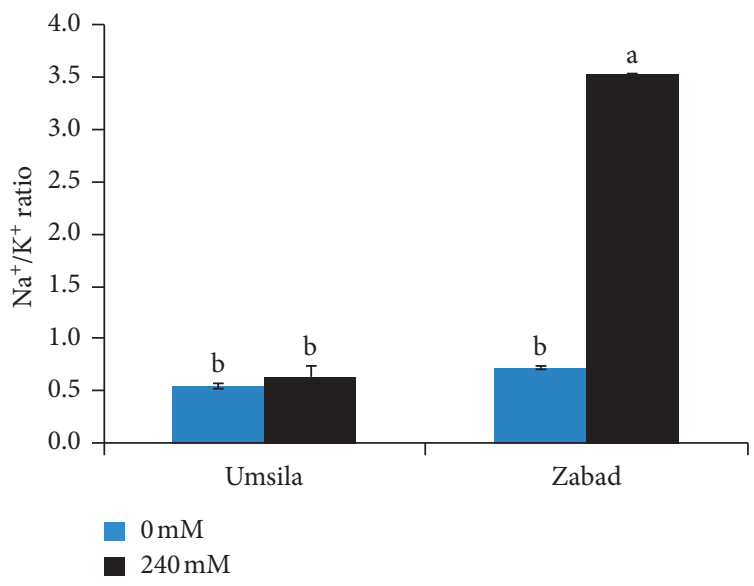

(e)

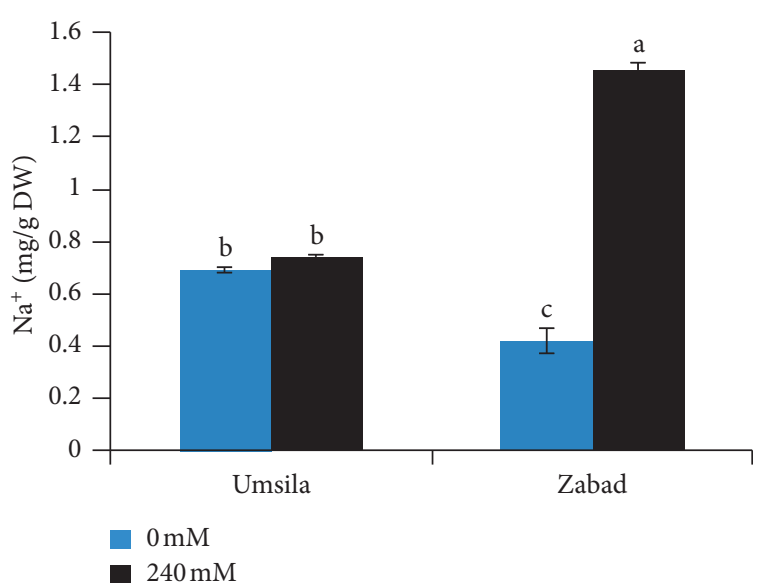

(b)

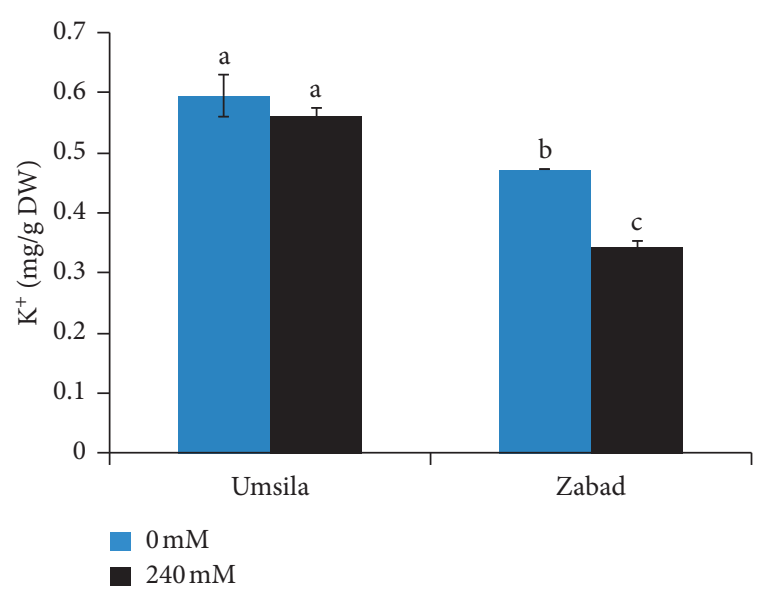

(d)

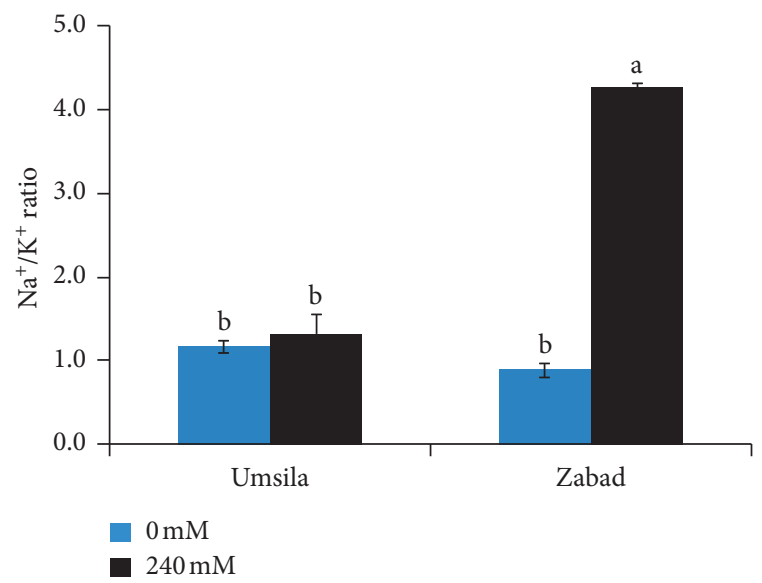

(f)

FIGURE 5: The effect of salinity on the accumulation of sodium $\left(\mathrm{Na}^{+}\right)$in leaves (a) and roots (b), the accumulation of potassium $\left(\mathrm{K}^{+}\right)$in leaves (c) and roots (d), and the $\mathrm{Na}^{+} / \mathrm{K}^{+}$ratio in leaves (e) and roots (f) of date palm seedlings when exposed to control $(0 \mathrm{mM} \mathrm{NaCl})$ and salinity $(240 \mathrm{mM} \mathrm{NaCl})$ conditions. Bars represent the mean $\pm \mathrm{SE}(n=3)$. Bars with the same letter are not significant at $p \leq 0.05$.

cultivar, than in Zabad. The better performance of salttolerant cultivar Umsila could be attributed to better maintenance of various morphological, physiological, and anatomical characteristics. For example, Umsila has a larger root system than Zabad. Moreover, the root system was less affected by salinity in Umsila. In fact, the root diameter and the total root tips have increased in response to salinity. This feature may enhance the water absorption as well as water holding capacity of the root under salinity and, therefore, promote tolerance [47]. 


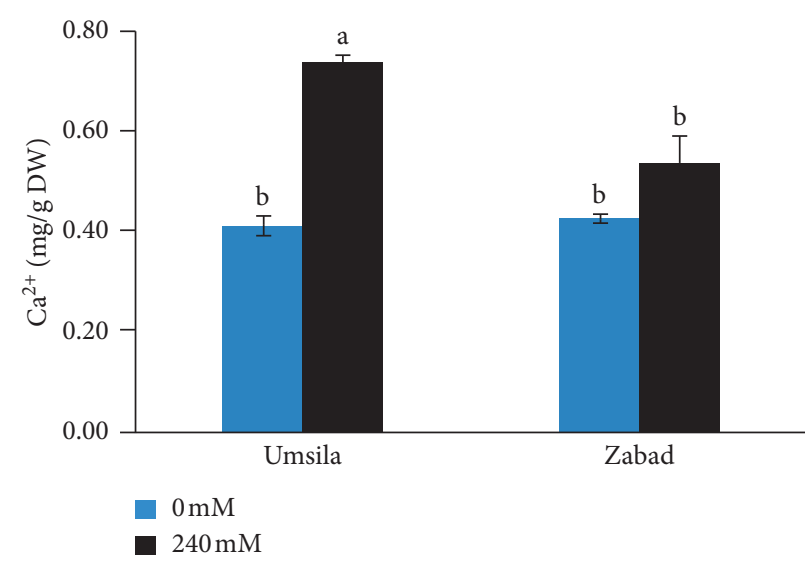

(a)

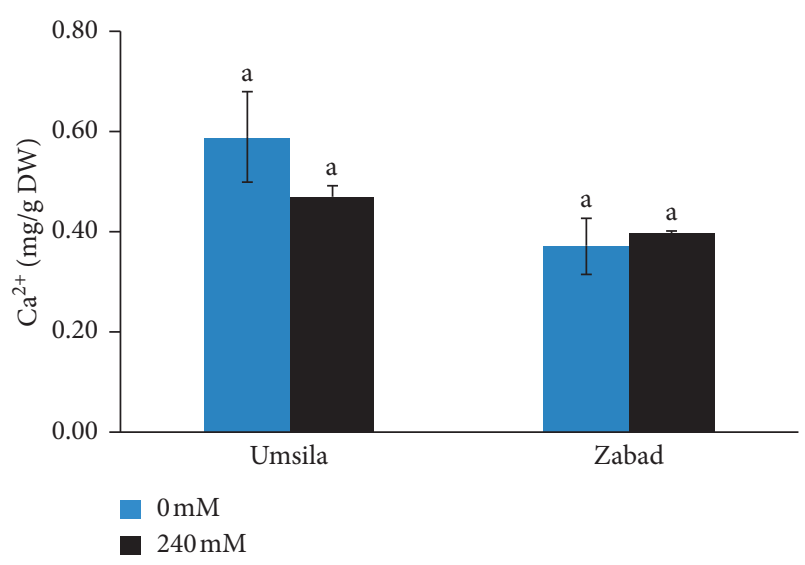

(b)

Figure 6: Effect of salinity on the calcium $\left(\mathrm{Ca}^{+2}\right)$ concentration in leaves (a) and roots (b) of date palm seedlings when grown under control and salinity conditions. Bars represent mean $\pm \mathrm{SE}(n=3)$. Bars with the same letter are not significant at $p \leq 0.05$.

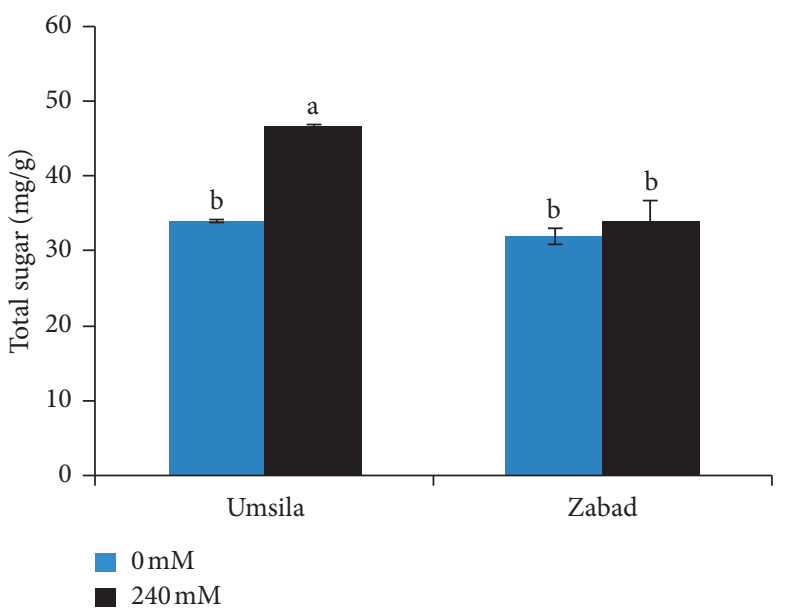

(a)

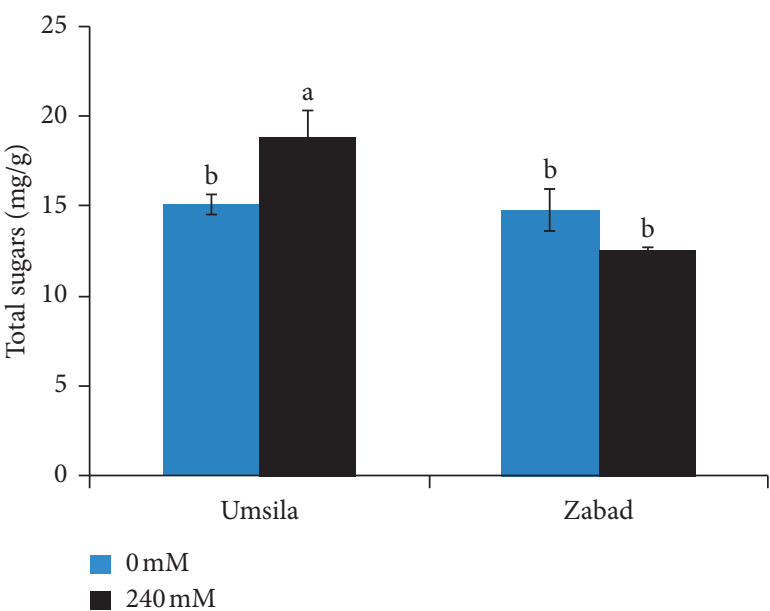

(b)

FiguRE 7: Differential accumulation of soluble sugars in leaves (a) and roots (b) of the salt-tolerant cultivar Umsila and susceptible Zabad cultivars due to salt treatment. Bars represent mean \pm SE $(n=3)$. Statistical differences between the treatments were calculated based on $p \leq 0.05$.

Umsila has maintained a better photosynthetic system under salinity than the susceptible cultivar Zabad as reflected by the relevant parameters measured in this study. In fact, maintaining the production of photosynthates such as starch is a natural abiotic response of various salt-tolerant plants [48]. These photosynthates provide an essential source of energy, which is required to combat the harsh conditions and may also transform into smaller molecules while moving toward the sink and, hence, serve as osmolytes that can help plants maintain osmotic potential [48].

Although the photosynthetic rate $(A)$ decreased in Umsila and Zabad, Umsila had a relatively higher value of $A$ than Zabad under salt stress, concomitant with higher levels of gs and $E$ (Figure 3). In the present study, the tolerant cultivar Umsila showed less use of TUE than the susceptible cultivar Zabad (Figure 3). TUE of the photosynthesis procedure is an indicator of efficient photosynthesis machinery
$[49,50]$. Besides, Qy was less reduced in Umsila than in Zabad. Damage to the photosynthetic machinery is often ascertained by measuring the quantum yield efficiency of PSII (Qy) [51-53]. Generally, higher $A$ is because of higher gs and $E$ is complemented by less use of TUE and, hence, are the major factors contributing in photosynthesis in the date palm as well as in other plant species [50,54, 55]. Reduction of $C i$ in the two cultivars under salinity stress could be due to the direct effect of the reduction in stomatal conductance (stomatal limitation) [56, 57]. The decline in photosynthesis could be direct, such as a decrease in $\mathrm{CO}_{2}$ concentration caused by stomatal closure or mesophyll conductance $[58,59]$, as it has been reported for other date palm cultivars [50, 60-62]. Umsila maintained a higher leaf area than Zabad under salt stress (Figure 1(b)), an indication of less growth and less photosynthesis reduction in this cultivar [63]. The leaf area is directly correlated with the 

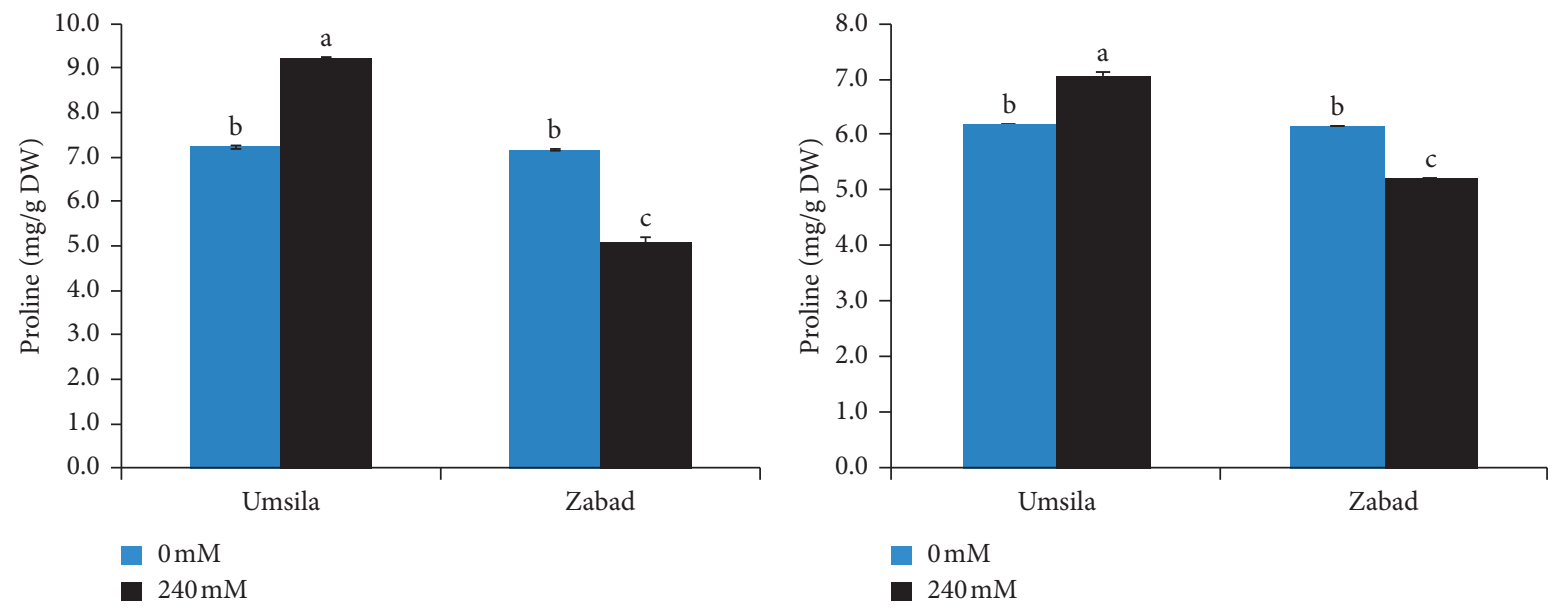

(a)

(b)
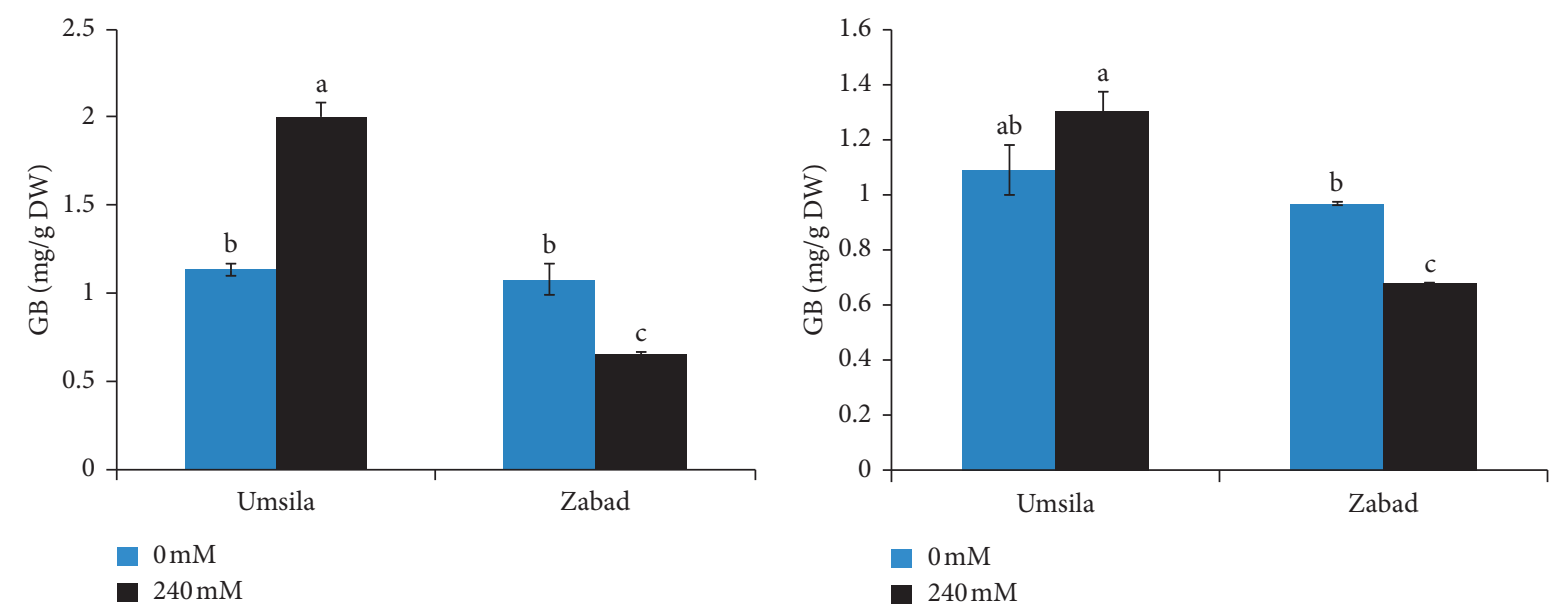

(c)

(d)

Figure 8: The effect of salinity on the accumulation of proline in leaves (a) and roots (b), and the accumulation of glycine betaine accumulation in leaves (c) and in roots (d) of date palm seedlings when exposed to control $(0 \mathrm{mM} \mathrm{NaCl})$ and salinity $(240 \mathrm{mM} \mathrm{NaCl})$ conditions. Bars represent the mean $\pm \mathrm{SE}(n=3)$. Statistical differences between the treatments were calculated based on $p \leq 0.05$.

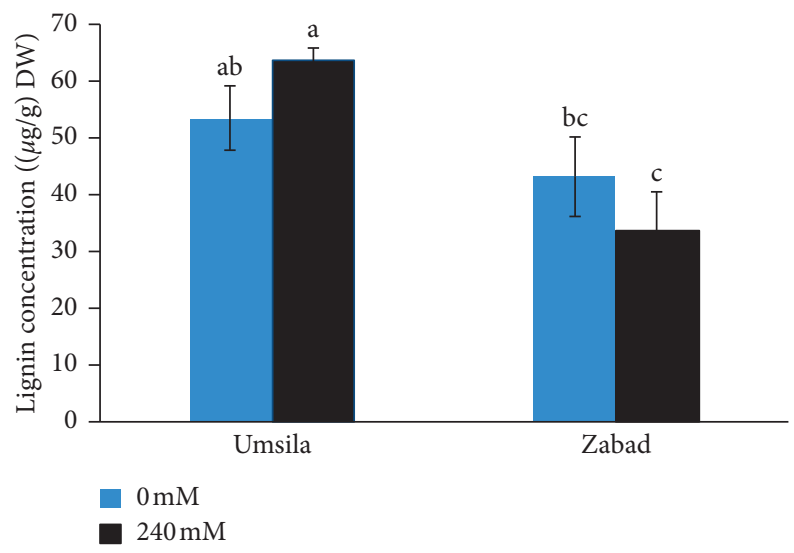

Figure 9: Effect of salinity on the lignin concentration in root tissues of date palm seedlings when grown under control and salinity conditions. Bars represent mean $\pm \mathrm{SE}(n=3)$. Bars with the same letter are not significant at $p \leq 0.05$.

photosynthetic rate [64]. These results suggest that photosynthesis is a crucial component of the stress-tolerant mechanism in the date palm.
Consistent with the higher photosynthesis efficiency, Umsila seedlings were able to accumulate more soluble sugars in their tissues than Zabad under salinity (Figure 7). 

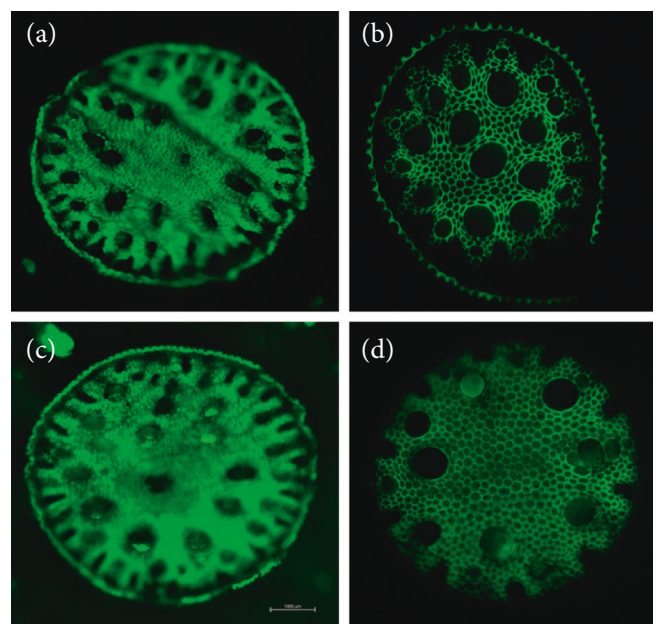

(a)

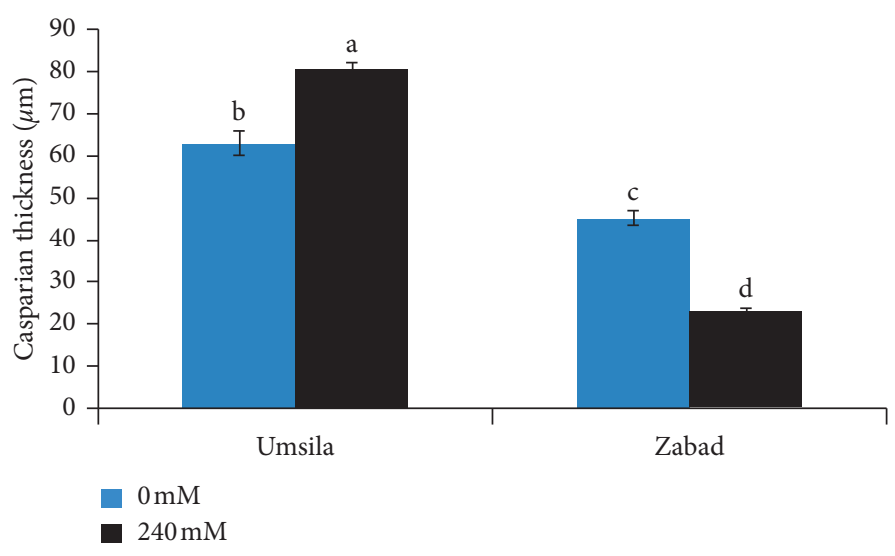

(b)

Figure 10: (a) Staining of Casparian strips of the date palm roots. Casparian strips staining of Umsila roots grown under control (a) and salinity conditions (b), and Zabad roots grown under control (c) and salinity conditions (d). (b) Bars represent mean of the Casparian strip thickness measured under the fluorescent microscope \pm SE $(n=3)$. Bars with the same letter are not significant at $p \leq 0.05$.

Soluble sugars act as osmolytes to maintain homeostasis in response to adverse environmental stresses $[17,65,66]$. Plants tend to increase the total soluble sugars in their tissues when exposed to salinity, a procedure which enhances salt tolerance [17]. For example, it was previously shown that the tolerant line ICMB 01222 of pearl millet had accumulated higher sugars in the leaves than the sensitive line ICMB 081 line under salt stress [67].

When compared with Zabad, Umsila cultivar maintained better plant-water relations because the seedlings were able to maintain better water potential and osmotic potential in leaves and roots under salinity. This was further reflected from the observation that the degree of reduction in the leaf area was more pronounced in Zabad. Cell expansion is a function of water uptake and cell wall extension [68]. Maintenance of the leaf area is primarily because of cell expansion which in turn is related to water status in the plants under salt stress. Salinity has affected water relations of both Umsila and Zabad by causing pronounced changes in LWP, RWC, OP, and OA. However, the degree of inhibition of these characteristics was much less in Umsila compared with Zabad. The lower OP values in the leaf and root tissues could be attributed to the fact that Zabad accumulates higher amounts of $\mathrm{Na}^{+}$than Umsila when grown under salinity. In addition, this reduction in OP might have further contributes toward the reduction LWP which in turn significantly $(p<0.05)$ affected the RWC of the salt-sensitive Zabab as compared with Umsila $[11,12]$ The overall improved water management system of the salt-tolerant Umsila can be related to the overall genetic makeup of the plant, rendering to its healthy physiology under salinity stress. Also, it was previously shown that transgenic Arabidopsis plants overexpressing the date palm gene, had improved water management under salinity and drought conditions.

It was observed that Umsila accumulates significantly $(p<0.05)$ high amounts of the osmolytes and compatible solutes as compared with Zabad under salinity stress. Furthermore, as reported previously, the proline and glycine betaine have increased in response to salinity in the date palm as well as in other plant species [69], where they play a pivotal role in mitigating $\mathrm{NaCl}$-induced $\mathrm{K}^{+}$efflux [70], and have a direct protective role for membrane integrity as an osmoprotectant under salt stress and other environmental stresses [71-73], as well as they have an indirect protective role through participating in signal transduction pathways [74]. It was previously reported that the accumulation of glycine betaine in the transgenic lines of wheat under salinity enhanced thylakoid membrane integrity and components resulted in higher photosynthesis [75].

Umsila was able to control $\mathrm{Na}^{+}$and retain $\mathrm{K}^{+}$content in the leaf and root tissues under salinity. On the other hand, reduction in $\mathrm{K}^{+}$ions in Zabad increased the possibility of $\mathrm{Na}^{+}$influx induced by the cytosolic $\mathrm{K}^{+}$efflux and leakages outside the cell and may cause accumulation of ROS [76]. The fact that Umsila has maintained a lower $\mathrm{Na}^{+} / \mathrm{K}^{+}$ratio is an indication that $\mathrm{K}^{+}$homeostasis is a critical feature in salt tolerance in the date palm as well as in other plant species [70]. One of the reasons this variation in the $\mathrm{Na}^{+} / \mathrm{K}^{+}$ratios could be the high accumulation of lignin in the Umsila than Zabad as observed in this study, these lignins may act as a barrier for the movement of $\mathrm{Na}^{+}$and $\mathrm{K}^{+}$ions [36]. Additionally, various ion transporters and channels are differentially expressed in different date palm varieties as a result of salinity, and this could further attribute to the variation in the $\mathrm{Na}^{+} / \mathrm{K}^{+}$ratios $[8,77]$.

Despite both the leaf OP and root OP was decreased in Umsila and Zabad under salinity, these parameters including LWP were less affected in Umsila, suggesting that this cultivar displayed a higher ability to extract water under saline conditions than salt-sensitive Zabad. This feature can be contributed to the capacity of this tolerant cultivar to lower the osmotic potential (osmotic adjustment) under salinity, likely through the production of sugars as shown in 
this report and also other osmolytes such as proline as previously shown [11]. It was previously shown that despite the low water potentials in Atriplex L. under salt stress, it could maintain cell turgor pressure and a favorable water absorption gradient because of the ability of this species to adjust osmotically [78-80].

$\mathrm{Na}^{+}$influx depolarizes the plasma membrane [81]. Therefore, the ability of plants to increase $\mathrm{Ca}^{2+}$ concentrations is vital for plants to tolerate salinity. In fact, $\mathrm{Ca}^{2+} \mathrm{can}$ block some of nonselective cationic channels; as a result, it reduces $\mathrm{Na}^{+}$permeability into cells, thereby maintaining the $\mathrm{Na}^{+} / \mathrm{K}^{+}$ratio balance $[82,83]$. Consistently, a previous study showed that water uptake and tolerance of Capsicum annuum L. under salinity were improved by exogenous application of $\mathrm{Ca}^{2+}$ [84]. In the current study, $\mathrm{Ca}^{2+}$ concentrations have increased in Umsila and Zabad leaves, however, remained lower in the root tissues of Zabad than those in Umsila under salinity. Most significantly, the reduction in $\mathrm{Ca}^{2+}$ concentrations in Zabad leaves increased the possibility of low relative water content. Reduction in tissue water content under salinity might change cytosolic $\mathrm{Ca}^{2+}$ concentrations $[68,85]$. A high amount of $\mathrm{Ca}^{2+}$ in Umsila leaves can be contributed to less negative LWP, which could maintain cell membrane depolarization and, thus, resulted in opening channels that allow movement of positive ions such as $\mathrm{Ca}^{+2}$ and $\mathrm{K}^{+}$into cells.

$\mathrm{Ca}^{2+}$ concentrations increased significantly in the leaves of Umsila than Zabad. $\mathrm{Ca}^{2+}$ substantially reduces the effects of the salt stress in many plants [70], and it is among early signaling events in plants with other signals such as ROS. $\mathrm{Ca}^{+}$ has a crucial signaling function in plant cells, where it regulates the membrane channel and stomatal movement, which are essential factors responsible for regulating $\mathrm{Na}^{+} / \mathrm{K}^{+}$uptake and plant water status as well as photosynthesis regulation $[86,87]$. Therefore, it is not unexpected that $\mathrm{Ca}^{+}$is actively involved in the salinity tolerance mechanism in date palms.

The Casparian strip thickness has increased in response to salinity in the Umsila cultivar (Figure 7(b)). This may enhance the apoplastic barriers and regulate hydraulic conductivity in roots and, therefore, prevent the nonselective apoplastic bypass of $\mathrm{Na}^{+}$into the stele tissues and, hence, increase salinity tolerance $[88,89]$. On the same lines, it was proposed that some plant species such as tobacco, beans, and maize tend to accelerate the growth of the exo- and endoderm cells including the Casparian strip tissues in response to salinity [89-91]. Additionally, physical interaction between $\mathrm{Na}^{+}$ions and the cation exchange sites on the cell wall might change the chemical composition of the cell wall under salt stress [32], which might help mitigate $\mathrm{Na}^{+}$effects to cope with salt stress and decreasing the $\mathrm{Na}^{+} / \mathrm{K}^{+}$ratio in Umsila.

Increased deposition of lignin in the stele and cortex tissues in response to salinity was reported in different plant species $[92,93]$. Further, a higher lignification level was reported in the root of salt-tolerant but not in the salt-sensitive durum wheat (Triticum turgidum) in response to salinity $[94,95]$. Moreover, a significant increase in the lignification in the monocotyledonous species reduces salts and other toxic solute movement into the stele [96]. On the other hand, a decreased deposition of lignin increases salt sensitivity to rice
[31]. Changes in the lignin content as a response to biotic and abiotic stress was also previously reported in the date palm [97-100]. Consistently, in general, the lignin content was maintained in salt-tolerant Umsila but decreased in Zabad, a slat-sensitive cultivar, under saline conditions.

\section{Conclusions}

The results obtained from this study revealed that the date palm can tolerate salinity using an efficient photosynthetic system as indicated by the higher Qy and GS found in the tolerant cultivar Umsila and also by better maintenance of plant-water relations, which can maintain relatively better water availability in the plant tissue as observed in the tolerant Umsila. This could be achieved by an efficient OA because of (at least partially) greater accumulation of soluble sugars, $\mathrm{Ca}^{+}$, and compatible solutes such as proline and glycine betaine compared with salt-sensitive Zabad. Besides, salt tolerance in the date palm is associated with the accumulation of lignin deposition and the formation of Casparian strips, which could perhaps enhance selective ion and water movements across the plant tissues and maintain a balanced $\mathrm{Na}^{+} / \mathrm{K}^{+}$ratio as it was shown in the salt-tolerant Umsila cultivar. Taken together, the majority of the measured parameters were less affected in salttolerant Umsila compared with salt-sensitive Zabad, suggesting that the impact of salt stress is better counteracted in the tolerant date palm.

\section{Data Availability}

All data generated or analyzed during this study are included within the article.

\section{Conflicts of Interest}

The authors declare that there are no conflicts of interest regarding the publication of this article.

\section{Authors' Contributions}

LAK conceived, designed, performed the experiments, analyzed data, wrote the manuscript; RS revised and edited the manuscript; RAY provided resources; and MWY designed the experiment, supervised the experiments, wrote the manuscript, and contributed reagents, materials, and analysis tools.

\section{Acknowledgments}

This project is supported by the generous grant no. 151 from The Research Council (TRC), Oman. The authors would like to thank Dr. Himanshu Patankar for critical reading of the manuscript.

\section{References}

[1] R. Munns and M. Tester, "Mechanisms of salinity tolerance," Annual Review of Plant Biology, vol. 59, no. 1, pp. 651-681, 2008.

[2] M. W. Yaish and P. P. Kumar, "Salt tolerance research in date palm tree (Phoenix dactylifera L.), past, present, and future perspectives," Frontiers in Plant Science, vol. 6, 2015. 
[3] S. Shabala, "Learning from halophytes: physiological basis and strategies to improve abiotic stress tolerance in crops," Annals of Botany, vol. 112, no. 7, pp. 1209-1221, 2013.

[4] D. V. M. Assaha, A. M. M. Mekawy, A. Ueda, and H. Saneoka, "Salinity-induced expression of HKT may be crucial for $\mathrm{Na}^{+}$exclusion in the leaf blade of huckleberry (Solanum scabrum Mill.), but not of eggplant (Solanum melongena L.)," Biochemical and Biophysical Research Communications, vol. 460, no. 2, pp. 416-421, 2015.

[5] O. Cotsaftis, D. Plett, N. Shirley, M. Tester, and M. Hrmova, "A two-staged model of $\mathrm{Na}^{+}$exclusion in rice explained by 3D modeling of HKT transporters and alternative splicing," PLoS One, vol. 7, no. 7, Article ID e39865, 2012.

[6] S. Fujimaki, T. Maruyama, N. Suzui, N. Kawachi, E. Miwa, and K. Higuchi, "Base to tip and long-distance transport of sodium in the root of common reed [Phragmites australis (cav.) trin. ex steud.] at steady state under constant high-salt conditions," Plant and Cell Physiology, vol. 56, no. 5, pp. 943-950, 2015.

[7] M. W. Yaish, A. Al-Lawati, I. Al-Harrasi, and H. V. Patankar, "Genome-wide DNA methylation analysis in response to salinity in the model plant caliph medic (Medicago truncatula)," BMC Genomics, vol. 19, no. 1, p. 78, 2018.

[8] M. W. Yaish, H. V. Patankar, D. V. M. Assaha, Y. Zheng, R. Al-Yahyai, and R. Sunkar, "Genome-wide expression profiling in leaves and roots of date palm (Phoenix dactylifera L.) exposed to salinity," BMC Genomics, vol. 18, no. 1, p. 246, 2017.

[9] M. W. Yaish, R. Sunkar, Y. Zheng, B. Ji, R. Al-Yahyai, and S. A. Farooq, "A genome-wide identification of the miRNAome in response to salinity stress in date palm (Phoenix dactylifera L.)," Frontiers in Plant Science, vol. 6, p. 946, 2015.

[10] G. A. Jana, L. Al Kharusi, R. Sunkar, R. Al-Yahyai, and M. W. Yaish, "Metabolomic analysis of date palm seedlings exposed to salinity and silicon treatments," Plant Signaling \& Behavior, vol. 14, no. 11, Article ID 1663112, 2019.

[11] L. Al Kharusi, R. Al Yahyai, and M. W. Yaish, "Antioxidant response to salinity in salt-tolerant and salt-susceptible cultivars of date palm," Agriculture, vol. 9, no. 1, p. 8, 2019.

[12] L. Al Kharusi, D. Assaha, R. Al-Yahyai, and M. Yaish, "Screening of date palm (Phoenix dactylifera L.) cultivars for salinity tolerance," Forests, vol. 8, no. 4, p. 136, 2017.

[13] H. V. Patankar, I. Al-Harrasi, L. Al Kharusi et al., "Overexpression of a metallothionein $2 \mathrm{~A}$ gene from date palm confers abiotic stress tolerance to yeast and Arabidopsis thaliana," International Journal of Molecular Sciences, vol. 20, no. 12, p. 2871, 2019.

[14] A. R. Sheldon, R. C. Dalal, G. Kirchhof, P. M. Kopittke, and N. W. Menzies, "The effect of salinity on plant-available water," Plant and Soil, vol. 418, no. 1-2, pp. 477-491, 2017.

[15] S. Negrão, S. M. Schmöckel, and M. Tester, "Evaluating physiological responses of plants to salinity stress," Annals of Botany, vol. 119, no. 1, pp. 1-11, 2017.

[16] M. W. Yaish, "Short communication proline accumulation is a general response to abiotic stress in the date palm tree (Phoenix dactylifera L.)," Genetics and Molecular Research, vol. 14, no. 3, pp. 9943-9950, 2015.

[17] W. Liang, X. Ma, P. Wan, and L. Liu, "Plant salt-tolerance mechanism: a review," Biochemical and Biophysical Research Communications, vol. 495, no. 1, pp. 286-291, 2018.

[18] R. Munns, "Comparative physiology of salt and water stress," Plant, Cell and Environment, vol. 25, no. 2, pp. 239-250, 2002.
[19] R. Munns and A. Termaat, "Whole-plant responses to salinity," Functional Plant Biology, vol. 13, no. 1, pp. 143-160, 1986.

[20] J. A. Hernandez and M. S. Almansa, "Short-term effects of salt stress on antioxidant systems and leaf water relations of pea leaves," Physiologia Plantarum, vol. 115, no. 2, pp. 251-257, 2002.

[21] L. Díaz-López, V. Gimeno, V. Lidón, I. Simón, V. Martínez, and F. García-Sánchez, "The tolerance of Jatropha curcas seedlings to $\mathrm{NaCl}$ : an ecophysiological analysis," Plant Physiology and Biochemistry, vol. 54, pp. 34-42, 2012.

[22] S. J. Roy, S. Negrão, and M. Tester, "Salt resistant crop plants," Current Opinion in Biotechnology, vol. 26, pp. 115124, 2014.

[23] R. Munns, R. A. James, and A. Läuchli, "Approaches to increasing the salt tolerance of wheat and other cereals," Journal of Experimental Botany, vol. 57, no. 5, pp. 1025-1043, 2006.

[24] H. Kaur, G. Sirhindi, R. Bhardwaj, M. Alyemeni, K. H. Siddique, and P. Ahmad, "28-homobrassinolide regulates antioxidant enzyme activities and gene expression in response to salt-and temperature-induced oxidative stress in Brassica juncea," Scientific Reports, vol. 8, no. 1, p. 8735, 2018.

[25] P. Ahmad, A. A. Abdel Latef, A. Hashem, E. F. Abd_Allah, S. Gucel, and L.-S. P. Tran, "Nitric oxide mitigates salt stress by regulating levels of osmolytes and antioxidant enzymes in chickpea," Frontiers in Plant Science, vol. 7, p. 347, 2016.

[26] M. Gilliham, M. Dayod, B. J. Hocking et al., "Calcium delivery and storage in plant leaves: exploring the link with water flow," Journal of Experimental Botany, vol. 62, no. 7, pp. 2233-2250, 2011.

[27] P. J. White, "The pathways of calcium movement to the xylem," Journal of Experimental Botany, vol. 52, no. 358, pp. 891-899, 2001.

[28] A. Rahman, K. Nahar, M. Hasanuzzaman, and M. Fujita, "Calcium supplementation improves $\mathrm{Na}^{+} / \mathrm{K}^{+}$ratio, antioxidant defense and glyoxalase systems in salt-stressed rice seedlings," Frontiers in Plant Science, vol. 7, p. 609, 2016.

[29] M. Singh, J. Kumar, S. Singh, V. P. Singh, and S. M. Prasad, "Roles of osmoprotectants in improving salinity and drought tolerance in plants: a review," Reviews in Environmental Science and Bio/Technology, vol. 14, no. 3, pp. 407-426, 2015.

[30] W. Van den Ende and R. Valluru, "Sucrose, sucrosyl oligosaccharides, and oxidative stress: scavenging and salvaging?," Journal of Experimental Botany, vol. 60, no. 1, pp. 9-18, 2008.

[31] Y. Toda, M. Yoshida, T. Hattori, and S. Takeda, "RICE SALT SENSITIVE3 binding to bHLH and JAZ factors mediates control of cell wall plasticity in the root apex," Plant Signaling \& Behavior, vol. 8, no. 11, Article ID e26256, 2013.

[32] C. S. Byrt, R. Munns, R. A. Burton, M. Gilliham, and S. Wege, "Root cell wall solutions for crop plants in saline soils," Plant Science, vol. 269, pp. 47-55, 2018.

[33] K. J. Foster and S. J. Miklavcic, "A comprehensive biophysical model of ion and water transport in plant roots. I. Clarifying the roles of endodermal barriers in the salt stress response," Frontiers in Plant Science, vol. 8, p. 1326, 2017.

[34] S. Naseer, Y. Lee, C. Lapierre, R. Franke, C. Nawrath, and N. Geldner, "Casparian strip diffusion barrier in Arabidopsis is made of a lignin polymer without suberin," Proceedings of the National Academy of Sciences, vol. 109, no. 25, pp. 10101-10106, 2012.

[35] S. Srivastava, R. K. Vishwakarma, Y. A. Arafat, S. K. Gupta, and B. M. Khan, "Abiotic stress induces change in cinnamoyl 
CoA reductase (CCR) protein abundance and lignin deposition in developing seedlings of leucaena leucocephala," Physiology and Molecular Biology of Plants, vol. 21, no. 2, pp. 197-205, 2015.

[36] Q. Liu, L. Luo, and L. Zheng, "Lignins: biosynthesis and biological functions in plants," International Journal of Molecular Sciences, vol. 19, no. 2, p. 335, 2018.

[37] P. R. Rhodes and K. Matsuda, "Water stress, rapid polyribosome reductions and growth," Plant Physiology, vol. 58, no. 5 , pp. 631-635, 1976.

[38] H. D. Barrs and P. E. Weatherley, "A re-examination of the relative turgidity technique for estimating water deficit in leaves," Australian Journal of Biological Sciences, vol. 15, no. 3, pp. 413-428, 1962.

[39] R. Sinclair and W. N. Venables, "An alternative method for analysing pressure-volume curves produced with the pressure chamber," Plant, Cell and Environment, vol. 6, no. 3, pp. 211-217, 1983.

[40] F. A. Loewus, "Improvement in anthrone method for determination of carbohydrates," Analytical Chemistry, vol. 24, no. 1, p. 219, 1952.

[41] R. Munns, P. A. Wallace, N. L. Teakle, and T. D. Colmer, "Measuring soluble ion concentrations $\left(\mathrm{Na}^{+}, \mathrm{K}^{+}, \mathrm{Cl}^{-}\right)$in salttreated plants," in Plant Stress Tolerance, pp. 371-382, Springer, Berlin, Germany, 2010.

[42] Z.-H. Ren, J.-P. Gao, L.-G. Li et al., "A rice quantitative trait locus for salt tolerance encodes a sodium transporter," Nature Genetics, vol. 37, no. 10, pp. 1141-1146, 2005.

[43] J. M. Maia, E. L. Voigt, S. L. Ferreira-Silva, A. de Vasconcelos Fontenele, C. E. C. Macêdo, and J. A. G. Silveira, "Differences in cowpea root growth triggered by salinity and dehydration are associated with oxidative modulation involving types I and III peroxidases and apoplastic ascorbate," Journal of Plant Growth Regulation, vol. 32, no. 2, pp. 376-387, 2013.

[44] L. S. Bates, R. P. Waldren, and I. D. Teare, "Rapid determination of free proline for water-stress studies," Plant and Soil, vol. 39, no. 1, pp. 205-207, 1973.

[45] C. M. Grieve and S. R. Grattan, "Rapid assay for determination of water soluble quaternary ammonium compounds," Plant and Soil, vol. 70, no. 2, pp. 303-307, 1983.

[46] M. C. Brundrett, D. E. Enstone, and C. A. Peterson, "A berberine-aniline blue fluorescent staining procedure for suberin, lignin, and callose in plant tissue," Protoplasma, vol. 146, no. 2-3, pp. 133-142, 1988.

[47] I. T. Koevoets, J. H. Venema, J. T. M. Elzenga, and C. Testerink, "Roots withstanding their environment: exploiting root system Architecture responses to abiotic stress to improve crop tolerance," Frontiers in Plant Science, vol. 7, p. 1335, 2016.

[48] S. Dong and D. M. Beckles, "Dynamic changes in the starchsugar interconversion within plant source and sink tissues promote a better abiotic stress response," Journal of Plant Physiology, vol. 234-235, pp. 80-93, 2019.

[49] G. Marino, T. Caruso, L. Ferguson, and F. Marra, "Gas exchanges and stem water potential define stress thresholds for efficient irrigation management in olive (Olea europea L.),"Water, vol. 10, no. 3, p. 342, 2018.

[50] J. Kruse, M. Adams, B. Winkler et al., "Optimization of photosynthesis and stomatal conductance in the date palm Phoenix dactylifera during acclimation to heat and drought," New Phytologist, vol. 223, no. 4, pp. 1973-1988, 2019.
[51] K. Maxwell and G. N. Johnson, "Chlorophyll fluorescence-a practical guide," Journal of Experimental Botany, vol. 51, no. 345, pp. 659-668, 2000.

[52] D. Hanelt, "Photosynthesis assessed by chlorophyll fluorescence," in Bioassays, pp. 169-198, Elsevier, Amsterdam, Netherlands, 2018.

[53] P. Malea, K. Charitonidou, I. Sperdouli, Z. Mylona, and M. Moustakas, "Zinc uptake, photosynthetic efficiency and oxidative stress in the seagrass Cymodocea nodosa exposed to $\mathrm{ZnO}$ nanoparticles," Materials, vol. 12, no. 13, p. 2101, 2019.

[54] Y. Li, H. Li, Y. Li, and S. Zhang, "Improving water-use efficiency by decreasing stomatal conductance and transpiration rate to maintain higher ear photosynthetic rate in drought-resistant wheat," The Crop Journal, vol. 5, no. 3, pp. 231-239, 2017.

[55] T. Lawson and S. Vialet-Chabrand, "Speedy stomata, photosynthesis and plant water use efficiency," New Phytologist, vol. 221, no. 1, pp. 93-98, 2019.

[56] M. M. Chaves, J. Flexas, and C. Pinheiro, "Photosynthesis under drought and salt stress: regulation mechanisms from whole plant to cell," Annals of Botany, vol. 103, no. 4, pp. 551-560, 2009.

[57] J. Galmés, H. Medrano, and J. Flexas, "Photosynthetic limitations in response to water stress and recovery in Mediterranean plants with different growth forms," New Phytologist, vol. 175, no. 1, pp. 81-93, 2007.

[58] J. Flexas, J. Bota, F. Loreto, G. Cornic, and T. D. Sharkey, "Diffusive and metabolic limitations to photosynthesis under drought and salinity in C3 plants," Plant Biology, vol. 6, no. 3, pp. 269-279, 2004.

[59] J. Flexas, A. Diaz-espejo, J. Galmés, R. Kaldenhoff, H. Medrano, and M. Ribas-carbo, "Rapid variations of mesophyll conductance in response to changes in $\mathrm{CO}_{2}$ concentration around leaves," Plant, Cell \& Environment, vol. 30, no. 10, pp. 1284-1298, 2007.

[60] O. Sperling, N. Lazarovitch, A. Schwartz, and O. Shapira, "Effects of high salinity irrigation on growth, gas-exchange, and photoprotection in date palms (Phoenix dactylifera L., cv. Medjool)," Environmental and Experimental Botany, vol. 99, pp. 100-109, 2014.

[61] S. Elshibli, E. Elshibli, and H. Korpelainen, "Growth and photosynthetic $\mathrm{CO}_{2}$ responses of date palm plants to water availability," Emirates Journal of Food and Agriculture, vol. 28, no. 1, pp. 58-65, 2016.

[62] T. Youssef and M. A. Awad, "Mechanisms of enhancing photosynthetic gas exchange in date palm seedlings (Phoenix dactylifera L.) under salinity stress by a 5 -aminolevulinic acid-based fertilizer," Journal of Plant Growth Regulation, vol. 27, no. 1, pp. 1-9, 2008.

[63] S. P. Yadav, R. Bharadwaj, H. Nayak, R. Mahto, R. K. Singh, and S. K. Prasad, "Impact of salt stress on growth, productivity and physicochemical properties of plants: a review," International Journal of Comparative Sociology, vol. 7, pp. 1793-1798, 2019.

[64] J. N. Banavath, T. Chakradhar, V. Pandit et al., "Stress inducible overexpression of AtHDG11 leads to improved drought and salt stress tolerance in peanut (Arachis hypogaea L.)," Frontiers in Chemistry, vol. 6, p. 34, 2018.

[65] A. K. Gupta and N. Kaur, "Sugar signalling and gene expression in relation to carbohydrate metabolism under abiotic stresses in plants," Journal of Biosciences, vol. 30, no. 5, pp. 761-776, 2005. 
[66] Z. Gengmao, H. Yu, S. Xing, L. Shihui, S. Quanmei, and W. Changhai, "Salinity stress increases secondary metabolites and enzyme activity in safflower," Industrial Crops and Products, vol. 64, pp. 175-181, 2015.

[67] H. Shinde, K. Tanaka, A. Dudhate et al., "Comparative de novo transcriptomic profiling of the salinity stress responsiveness in contrasting pearl millet lines," Environmental and Experimental Botany, vol. 155, pp. 619-627, 2018.

[68] G. R. Cramer, "Sodium-calcium interactions under salinity stress," in Salinity: Environment-Plants-Molecules, pp. 205-227, Springer, Berlin, Germany, 2002.

[69] S. Gupta, M. R. Goyal, and A. Singh, "Physiological and biochemical changes in plants under soil salinity stress: a review," in Engineering Practices for Management of Soil Salinity, pp. 159-200, Apple Academic Press, Cambridge, MA, USA, 2018.

[70] S. Shabala, T. A. Cuin, L. Shabala, and I. Newman, "Quantifying kinetics of net ion fluxes from plant tissues by non-invasive microelectrode measuring MIFE technique," in Plant Salt Tolerance, pp. 119-134, Springer, Berlin, Germany, 2012.

[71] X.-Y. Zhang, C. Liang, G.-P. Wang, Y. Luo, and W. Wang, "The protection of wheat plasma membrane under cold stress by glycine betaine overproduction," Biologia Plantarum, vol. 54, no. 1, pp. 83-88, 2010.

[72] C. He, A. Yang, W. Zhang, Q. Gao, and J. Zhang, "Improved salt tolerance of transgenic wheat by introducing betA gene for glycine betaine synthesis," Plant Cell, Tissue and Organ Culture (PCTOC), vol. 101, no. 1, pp. 65-78, 2010.

[73] L. Hu, T. Hu, X. Zhang, H. Pang, and J. Fu, "Exogenous glycine betaine ameliorates the adverse effect of salt stress on perennial ryegrass," Journal of the American Society for Horticultural Science, vol. 137, no. 1, pp. 38-46, 2012.

[74] M. Tanveer and S. Shabala, "For salinity stress tolerance in crops," Salinity Responses and Tolerance in plants, vol. 1, pp. 213-214, 2018.

[75] F. Tian, W. Wang, C. Liang, X. Wang, G. Wang, and W. Wang, "Overaccumulation of glycine betaine makes the function of the thylakoid membrane better in wheat under salt stress," The Crop Journal, vol. 5, no. 1, pp. 73-82, 2017.

[76] L. H. Wegner and S. Shabala, "Biochemical pH clamp: the forgotten resource in membrane bioenergetics," New Phytologist, 2019.

[77] O. Radwan, J. Arro, C. Keller, and S. S. Korban, "RNA-Seq transcriptome analysis in date palm suggests multi-dimensional responses to salinity stress," Tropical Plant Biology, vol. 8, no. 3-4, pp. 74-86, 2015.

[78] M. Benzarti, K. B. Rejeb, D. Messedi et al., "Effect of high salinity on Atriplex portulacoides: growth, leaf water relations and solute accumulation in relation with osmotic adjustment," South African Journal of Botany, vol. 95, pp. 70-77, 2014.

[79] C. M. T. Lins, E. R. de Souza, H. F. de Melo et al., "Pressurevolume (PV) curves in Atriplex nummularia Lindl. for evaluation of osmotic adjustment and water status under saline conditions," Plant Physiology and Biochemistry, vol. 124, pp. 155-159, 2018.

[80] R. Munns, J. B. Passioura, T. D. Colmer, and C. S. Byrt, "Osmotic adjustment and energy limitations to plant growth in saline soil," New Phytologist, 2019.

[81] V. Demidchik, S. N. Shabala, K. B. Coutts, M. A. Tester, and J. M. Davies, "Free oxygen radicals regulate plasma membrane $\mathrm{Ca}^{2+}$ - and $\mathrm{K}^{+}$-permeable channels in plant root cells," Journal of Cell Science, vol. 116, no. 1, pp. 81-88, 2003.
[82] M. Tester and R. Davenport, " $\mathrm{Na}^{+}$tolerance and $\mathrm{Na}^{+}$ transport in higher plants," Annals of Botany, vol. 91, no. 5, pp. 503-527, 2003.

[83] V. Demidchik and F. J. M. Maathuis, "Physiological roles of nonselective cation channels in plants: from salt stress to signalling and development," New Phytologist, vol. 175, no. 3, pp. 387-404, 2007.

[84] F. J. Cabañero, V. Martínez, and M. Carvajal, "Does calcium determine water uptake under saline conditions in pepper plants, or is it water flux which determines calcium uptake?," Plant Science, vol. 166, no. 2, pp. 443-450, 2004.

[85] V. Demidchik, S. Shabala, S. Isayenkov, T. A. Cuin, and I. Pottosin, "Calcium transport across plant membranes: mechanisms and functions," New Phytologist, vol. 220, no. 1, pp. 49-69, 2018.

[86] V. Demidchik and S. Shabala, "Mechanisms of cytosolic calcium elevation in plants: the role of ion channels, calcium extrusion systems and NADPH oxidase-mediated "ROS$\mathrm{Ca}^{2+}$ Hub", "Functional Plant Biology, vol. 45, no. 2, pp. 9-27, 2018.

[87] S. S. Medvedev, "Principles of calcium signal generation and transduction in plant cells," Russian Journal of Plant Physiology, vol. 65, no. 6, pp. 771-783, 2018.

[88] H. M. Zimmermann, K. Hartmann, L. Schreiber, and E. Steudle, "Chemical composition of apoplastic transport barriers in relation to radial hydraulic conductivity of corn roots (Zea mays L.)," Planta, vol. 210, no. 2, pp. 302-311, 2000.

[89] I. Karahara, A. Ikeda, T. Kondo, and Y. Uetake, "Development of the Casparian strip in primary roots of maize under salt stress," Planta, vol. 219, no. 1, pp. 41-47, 2004.

[90] D. Reinhardt and T. Rost, "Salinity accelerates endodermal development and induces an exodermis in cotton seedling roots," Environmental and Experimental Botany, vol. 35, no. 4, pp. 563-574, 1995.

[91] L. Schreiber, R. Franke, and K. Hartmann, "Effects of no 3 deficiency and $\mathrm{NaCl}$ stress on suberin deposition in rhizoand hypodermal (RHCW) and endodermal cell walls (ECW) of castor bean (Ricinus communis L.) roots," Plant and Soil, vol. 269, no. 1-2, pp. 333-339, 2005.

[92] C. Nawrath, L. Schreiber, R. B. Franke, N. Geldner, J. J. Reina-Pinto, and L. Kunst, "Apoplastic diffusion barriers in Arabidopsis," The Arabidopsis Book/American Society of Plant Biologists, vol. 11, Article ID e0167, 2013.

[93] R. T. Cruz, W. R. Jordan, and M. C. Drew, "Structural changes and associated reduction of hydraulic conductance in roots of Sorghum bicolor L. following exposure to water deficit," Plant Physiology, vol. 99, no. 1, pp. 203-212, 1992.

[94] H. Wu, L. Shabala, E. Azzarello et al., " $\mathrm{Na}^{+}$extrusion from the cytosol and tissue-specific $\mathrm{Na}^{+}$sequestration in roots confer differential salt stress tolerance between durum and bread wheat," Journal of Experimental Botany, vol. 69, no. 16, pp. 3987-4001, 2018.

[95] R. Munns, R. A. Hare, R. A. James, and G. J. Rebetzke, "Genetic variation for improving the salt tolerance of durum wheat," Australian Journal of Agricultural Research, vol. 51, no. 1, pp. 69-74, 2000.

[96] J. Zeier and L. Schreiber, "Comparative investigation of primary and tertiary endodermal cell walls isolated from the roots of five monocotyledoneous species: chemical composition in relation to fine structure," Planta, vol. 206, no. 3, pp. 349-361, 1998. 
[97] A. El Hadrami, F. Daayf, and I. El Hadrami, "Secondary metabolites of date palm," in Date Palm Biotechnology, pp. 653-674, Springer, Berlin, Germany, 2011.

[98] C. El Modafar, A. Tantaoui, and E.-S. El Boustani, "Differential induction of phenylalanine ammonia-lyase activity in date palm roots in response to inoculation with Fusarium oxysporum $\mathrm{f}$. $\mathrm{sp}$. albedinis and to elicitation with fungal wall elicitor," Journal of Plant Physiology, vol. 158, no. 6, pp. 715-722, 2001.

[99] S. D. Karlen, R. A. Smith, H. Kim et al., "Highly decorated lignins in leaf tissues of the Canary Island date palm Phoenix canariensis," Plant Physiology, vol. 175, no. 3, pp. 1058-1067, 2017.

[100] B. F. Abu-Sharkh and H. Hamid, "Degradation study of date palm fibre/polypropylene composites in natural and artificial weathering: mechanical and thermal analysis," Polymer Degradation and Stability, vol. 85, no. 3, pp. 967-973, 2004. 


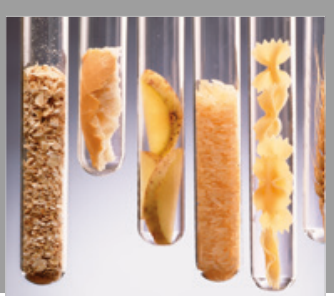

International Journal of Food Science

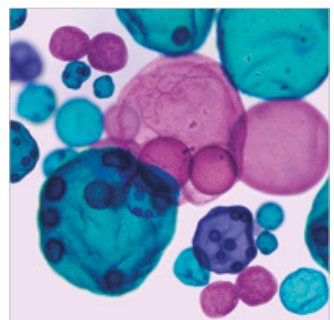

International Journal of Microbiology
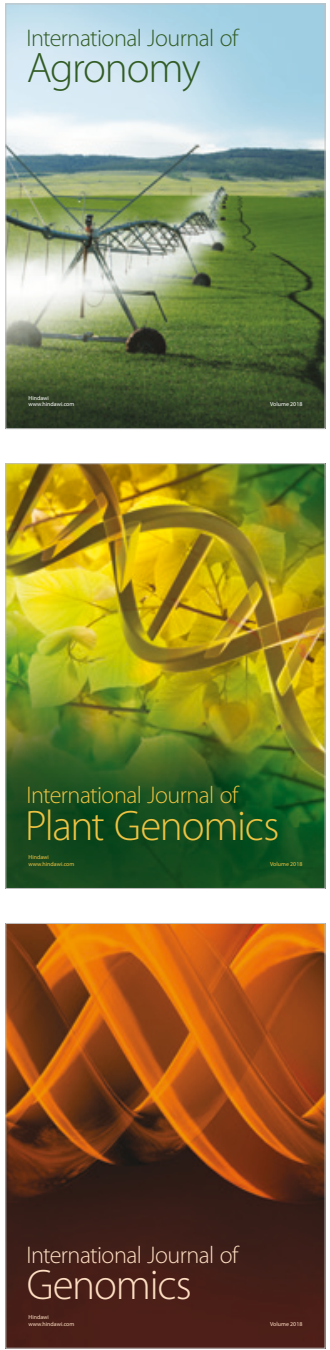

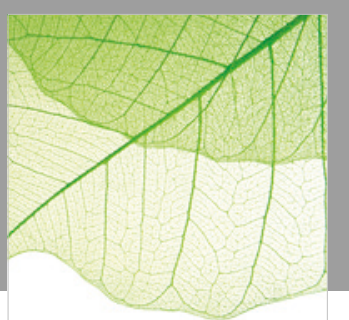

Journal of Botany
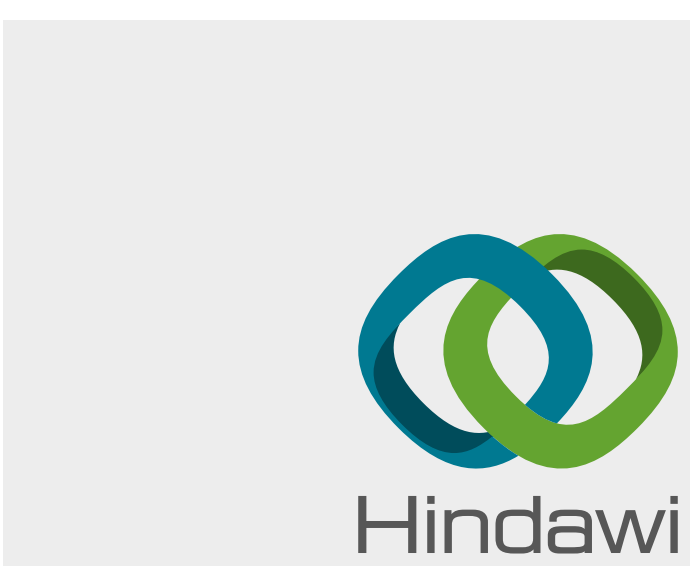

Submit your manuscripts at

www.hindawi.com
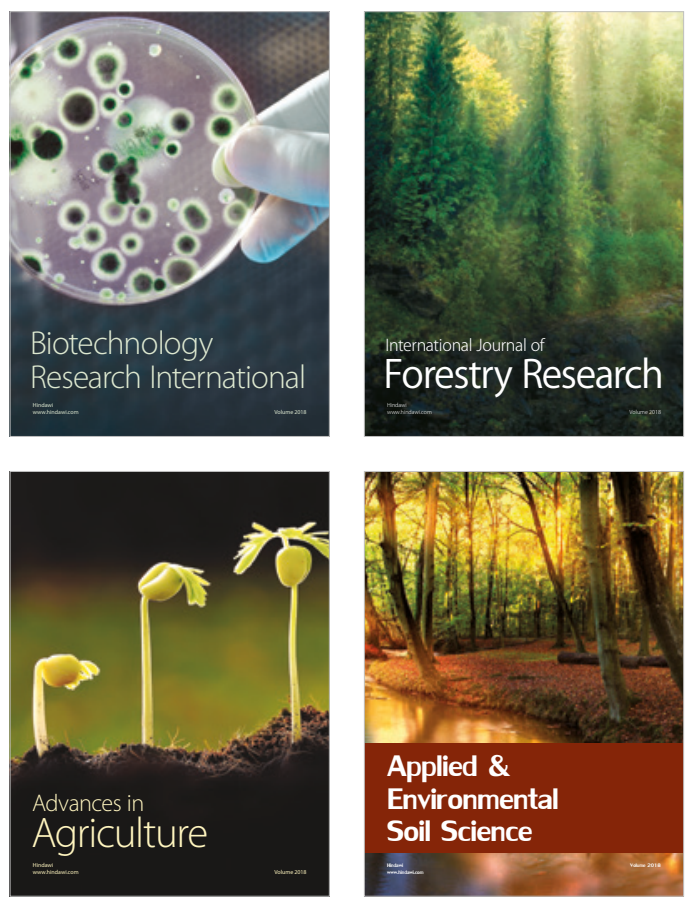

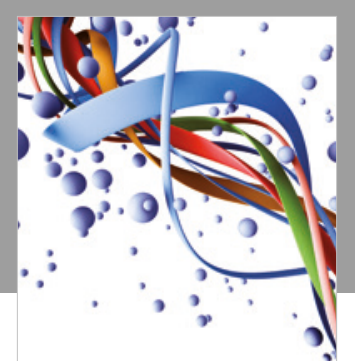

Scientifica

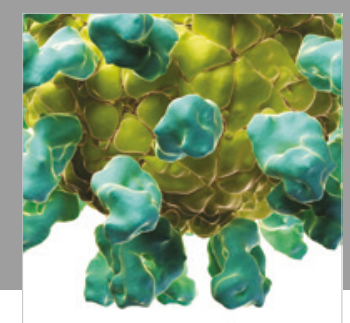

Veterinary Medicine International

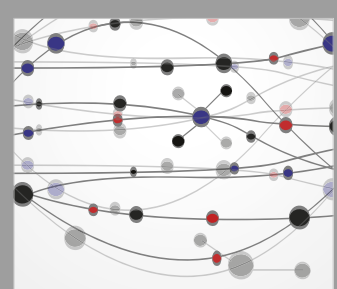

The Scientific World Journal
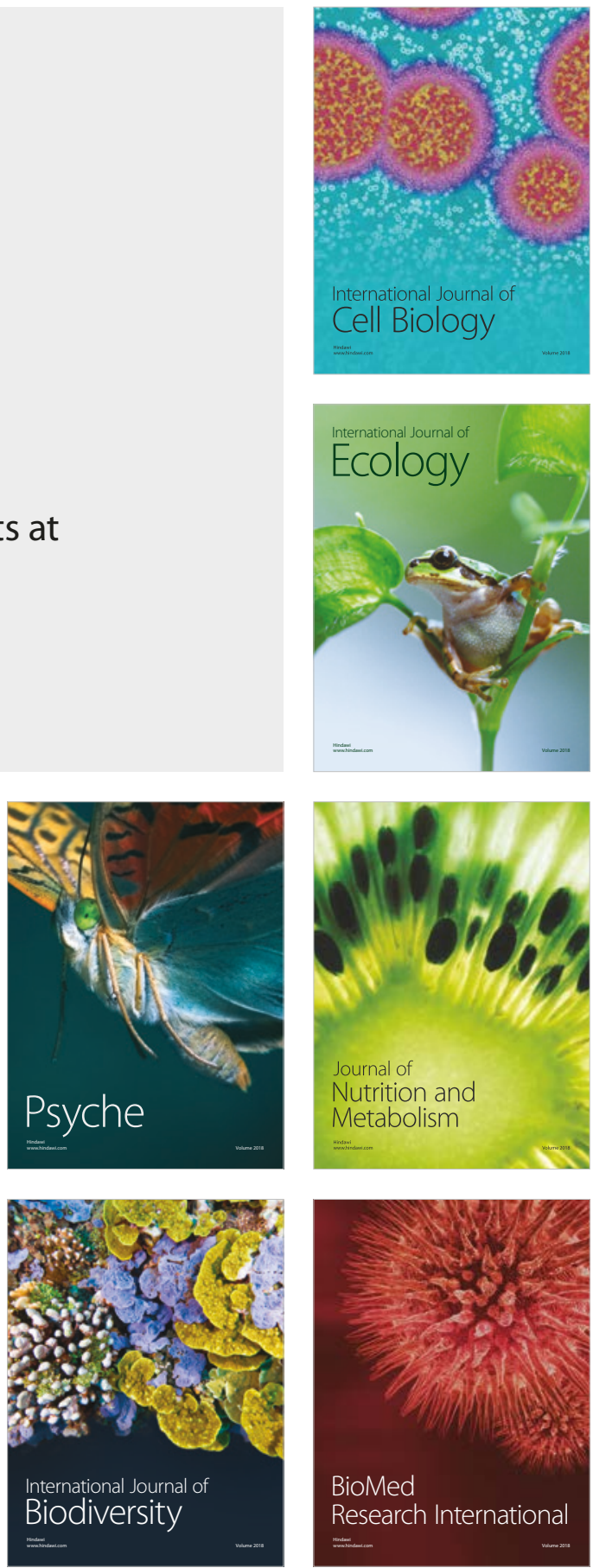